Western University

Scholarship@Western

Chemistry Publications

Chemistry Department

Winter 2018

Dialkynylborane Complexes of Formazanate Ligands: Synthesis, Electronic Properties, and Reactivity

Alex Van Belois

Ryan R. Maar

Mark S. Workentin

Joe Gilroy

jgilroy5@uwo.ca

Follow this and additional works at: https://ir.lib.uwo.ca/chempub

Part of the Chemistry Commons

Citation of this paper:

Van Belois, Alex; Maar, Ryan R.; Workentin, Mark S.; and Gilroy, Joe, "Dialkynylborane Complexes of Formazanate Ligands: Synthesis, Electronic Properties, and Reactivity" (2018). Chemistry Publications. 98.

https://ir.lib.uwo.ca/chempub/98 


\title{
Dialkynylborane Complexes of Formazanate Ligands: Synthesis, Electronic Properties, and Reactivity
}

\author{
Alex Van Belois, Ryan R. Maar, Mark S. Workentin*, and Joe B. Gilroy* \\ Department of Chemistry and the Centre for Advanced Materials and Biomaterials Research \\ (CAMBR), The University of Western Ontario, London, Ontario, Canada, N6A 5B7.
}




\begin{abstract}
Dialkynylborane complexes of $N$-donor ligands have received significant attention due to their application in biological imaging, as light-harvesting materials, and as the functional component of organic photovoltaics. Despite these advances, relatively few types of $N$-donor ligands have been explored in this context. To this end, we prepared a series of dialkynylborane complexes of formazanate ligands and explored their electronic properties and reactivity. In doing so, we demonstrated that: 1) The nature of the alkynyl substituents has little influence over the UV-vis absorption properties of the title complexes, but does affect the potentials at which they are electrochemically oxidized and reduced. 2) Dialkynylborane formazanate complexes can be converted to stable radical anions by chemical reduction with cobaltocene derivatives. 3 ) Copper-assisted alkyne-azide cycloaddition chemistry at the alkynyl substituents directly bound to boron can be used to elaborate structural diversity. These conclusions are likely to lead to the development of, and provide guiding principles for the design of, future examples of functional molecular materials based on boron complexes of $\mathrm{N}$-donor ligands.
\end{abstract}

\title{
INTRODUCTION
}

Fluoride-substituted boron dipyrromethenes (F-BODIPYs, 1), which benefit from structural rigidity and advantageous push-pull electronics due to the presence of the boron difluoride $\left(\mathrm{BF}_{2}\right)$ moiety, are one of the most widely studied classes of molecular dyes and have seen extensive use as fluorescence probes and imaging agents. ${ }^{1-4}$ One of the most attractive features of their chemistry is the ability to tune the absorption and emission properties through

structural variation of the dipyrromethene scaffold at the $\mathrm{R}^{1}-\mathrm{R}^{8}$ positions, or by incorporation of a third nitrogen atom in the ligand framework to form aza-BODIPYs (2). Despite the widespread 
use of such structural modification strategies, the synthesis of BODIPYs and their modification can be synthetically challenging, low-yielding, and expensive.

In an effort to circumvent some of these challenges, Ziessel and co-workers produced the first examples of dialkynylborane complexes of dipyrromethenes (E-BODIPYs, 3 ) in the mid$2000 \mathrm{~s},{ }^{5-6}$ which can be prepared via the reaction of $F$-BODIPYs with the lithium salts of substituted alkynes. Over the past decade, the chemistry of $E$-BODIPYs and related compounds derived from $a z a$-BODIPYs (4) has expanded significantly ${ }^{7-13}$ and these compounds have been used extensively as light-harvesting arrays ${ }^{14-17}$ and dye lasers, ${ }^{18-19}$ in biological imaging, ${ }^{20-24}$ as the functional component of photovoltaic cells, ${ }^{25-28}$ and as building blocks for functional assemblies. ${ }^{29-37}$ Given these advances, it may be surprising that dialkynylborane complexes of relatively few classes of $\mathrm{N}$-donor ligands have been explored to date.

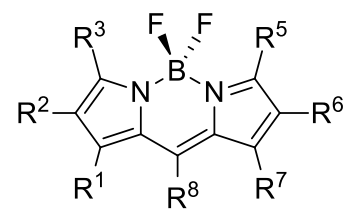

1, F-BODIPY

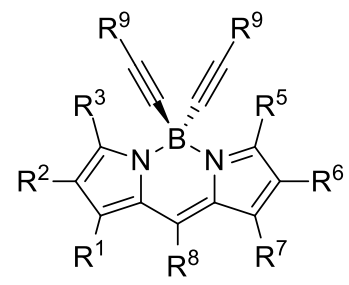

3, E-BODIPY

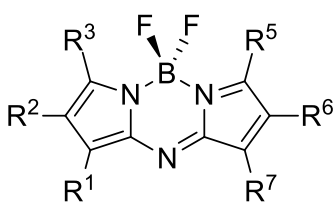

2, aza-BODIPY

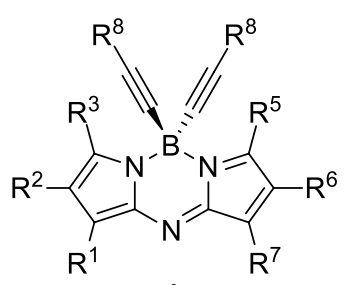

4

Recently, transition metal complexes of formazanate ligands (5) have received significant attention $^{38-52}$ and their $\mathrm{BF}_{2}$ complexes $(6)$ have emerged as attractive alternatives to $F$-BODIPYs as a result of their relatively straightforward and inexpensive syntheses and their tuneable absorption/emission and redox properties. ${ }^{53-59}$ As a result, the latter have found application as cell-imaging agents, ${ }^{56,59}$ electrochemiluminescence (ECL) emitters, ${ }^{60-61}$ precursors to a wide 
range of unusual $\mathrm{BN}$ heterocycles, ${ }^{62-63}$ building blocks for multifunctional polymers, ${ }^{64-67}$ and to promote $\mathrm{N}-\mathrm{H}$ and $\mathrm{N}-\mathrm{C}$ bond homolysis. ${ }^{68}$

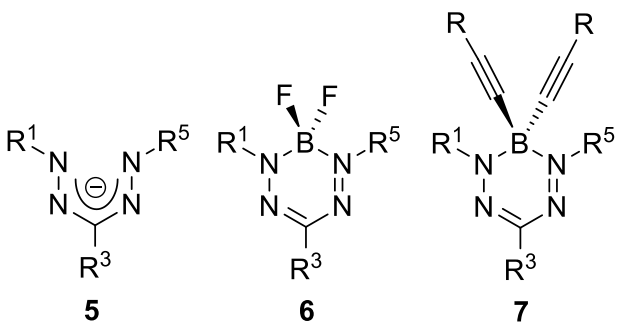

Herein, we build on previous reports describing the effects of substituent variation at the formazanate backbone $e^{54-55,58,69}$ by synthesizing the first examples of alkynylborane complexes of formazanate ligands (7) and studying their electronic properties and reactivity. These complexes represent the first discrete boron adducts of formazanate ligands prepared by the substitution of the fluorine atoms of $\mathrm{BF}_{2}$ formazanates.

\section{EXPERIMENTAL SECTION}

\section{General Considerations}

Solvents were obtained from Caledon Laboratories, dried using an Innovative Technologies Inc. solvent purification system, collected under vacuum, and stored under an $\mathrm{N}_{2}$ atmosphere over $4 \AA$ molecular sieves. All other reagents were purchased from Sigma Aldrich, Alfa Aesar or Oakwood Chemical and used as received. 1,3,5-tri-p-tolylformazan $\mathbf{8}$ was prepared according to a literature procedure. ${ }^{70} \mathrm{NMR}$ spectra were recorded on a Bruker $400 \mathrm{MHz}$ NMR spectrometer, $400 \mathrm{MHz}$ Varian INova NMR spectrometer, or $600 \mathrm{MHz}$ Varian Inova NMR spectrometer. ${ }^{1} \mathrm{H}$ NMR spectra were recorded in $\mathrm{CDCl}_{3}$ or $\mathrm{CD}_{2} \mathrm{Cl}_{2}$ and referenced against residual protonated solvent at 7.27 and $5.32 \mathrm{ppm}$, respectively. ${ }^{13} \mathrm{C}\left\{{ }^{1} \mathrm{H}\right\}$ NMR spectra were referenced to $\mathrm{CDCl}_{3}$ at 77.0 ppm. ${ }^{11} \mathrm{~B}$ NMR spectra were referenced internally to $\mathrm{BF}_{3} \cdot \mathrm{OEt}_{2}$ at 0 ppm. ${ }^{19} \mathrm{~F}$ NMR spectra 
were referenced internally to $\mathrm{CFCl}_{3}$ at $0 \mathrm{ppm}$. Mass spectra were recorded in positive-ion or negative-ion mode using a Bruker microTOF II electrospray ionization spectrometer. UV-vis absorption spectra were recorded using a Cary 5000 Scan instrument using standard quartz cells (1 cm path length) with a scan range of 200 to $1200 \mathrm{~nm}$. Samples were dissolved in spectroscopic grade solvents to obtain various concentrations. The background was subtracted from each spectrum and the solvent used for each experiment is indicated. FT-IR spectra were recorded using a Perkin Elmer Spectrum Two FT-IR spectrometer.

\section{Cyclic Voltammetry}

Cyclic voltammetry experiments were performed using a Bioanalytical Systems Inc. (BASi) Epsilon potentiostat and analyzed using BASi Epsilon software. Typical electrochemical cells consisted of a three-electrode setup including a glassy carbon working electrode, platinum counter electrode, and silver pseudo reference electrode. Experiments were run at $50-1000 \mathrm{mV} \mathrm{s}^{-1}$ in degassed $\mathrm{CH}_{2} \mathrm{Cl}_{2}$ solutions of the analyte $(\sim 1 \mathrm{mM})$ and electrolyte $(0.1 \mathrm{M}$ $\left.\left[n \mathrm{Bu}_{4} \mathrm{~N}\right]\left[\mathrm{PF}_{6}\right]\right)$. Cyclic voltammograms were internally referenced against the ferrocene/ferrocenium redox couple $(\sim 1 \mathrm{mM}$ internal standard $)$ and corrected for internal cell resistance using the BASi Epsilon software. The CV obtained for complex 10d was referenced against the ferrocene/ferrocenium redox couple using decamethylferrocene/ decamethylferrocenium ( $-520 \mathrm{mV}$ vs ferrocene/ferrocenium under identical conditions) as an internal reference.

\section{Electron Paramagnetic Resonance (EPR) Spectroscopy}

EPR measurements were made for degassed $10 \mu \mathrm{M}$ THF solutions of radical anions $\mathbf{1 0 a}^{-{ }^{-}}$and 10d $^{--}$using a JEOL JES-FA200 EPR spectrometer. All measurements were made at $21{ }^{\circ} \mathrm{C}$ and $g$ factors were referenced relative to a built-in $\mathrm{Mn}^{2+}$ marker within the resonant cavity of the 
instrument.

BF 2 Complex 9: Under $\mathrm{N}_{2}$, formazan 8 (1.0 g, $\left.3.0 \mathrm{mmol}\right)$ was dissolved in dry toluene (100 $\left.\mathrm{mL}\right)$. $\mathrm{NEt}_{3}(1.4 \mathrm{~mL}, 10 \mathrm{mmol})$ was then added dropwise and the solution was stirred for $5 \mathrm{~min}$. $\mathrm{BF}_{3} \cdot \mathrm{OEt}_{2}(1.9 \mathrm{~mL}, 15 \mathrm{mmol})$ was then added, and the solution was heated at $80{ }^{\circ} \mathrm{C}$ for $18 \mathrm{~h}$. The solution changed from dark red to dark purple during this time. The solution was then cooled to room temperature and $\mathrm{H}_{2} \mathrm{O}(20 \mathrm{~mL})$ was added to quench any reactive boron-containing compounds. The solution was then washed with deionized $\mathrm{H}_{2} \mathrm{O}(3 \times 50 \mathrm{~mL})$, dried over $\mathrm{MgSO}_{4}$, gravity filtered and concentrated in vacuo. The resulting residue was purified by flash chromatography $\left(\mathrm{CH}_{2} \mathrm{Cl}_{2}\right.$, neutral alumina) to afford the $\mathrm{BF}_{2}$ complex 9 as a dark purple microcrystalline solid after solvent removal in vacuo. Yield $=0.98 \mathrm{~g}(86 \%)$. M.p. $166-168{ }^{\circ} \mathrm{C}$. ${ }^{1} \mathrm{H}$ NMR $\left(399.8 \mathrm{MHz}, \mathrm{CDCl}_{3}\right): \delta 7.99\left(\mathrm{~d},{ }^{3} J_{\mathrm{HH}}=8 \mathrm{~Hz}, 2 \mathrm{H}\right.$, Aryl $\left.\mathrm{CH}\right), 7.80\left(\mathrm{~d},{ }^{3} J_{\mathrm{HH}}=8 \mathrm{~Hz}, 4 \mathrm{H}\right.$, Aryl $\mathrm{CH}$ ), 7.29-7.26 (m, 6H, Aryl $\mathrm{CH}), 2.43\left(\mathrm{~s}, 3 \mathrm{H}, \mathrm{CH}_{3}\right), 2.42\left(\mathrm{~s}, 6 \mathrm{H}, \mathrm{CH}_{3}\right) .{ }^{11} \mathrm{~B}$ NMR $\left(128.3 \mathrm{MHz}, \mathrm{CDCl}_{3}\right): \delta-0.5\left(\mathrm{t},{ }^{1} J_{\mathrm{BF}}=29 \mathrm{~Hz}\right) .{ }^{13} \mathrm{C}\left\{{ }^{1} \mathrm{H}\right\} \mathrm{NMR}\left(101.6 \mathrm{MHz}, \mathrm{CDCl}_{3}\right): \delta 149.0$ $141.7,140.0,139.1,131.1,129.6,129.4,125.4,123.2,21.34,21.32 .{ }^{19} \mathrm{~F} \mathrm{NMR}(376.1 \mathrm{MHz}$, $\left.\mathrm{CDCl}_{3}\right): \delta-145.0\left(\mathrm{q},{ }^{1} J_{\mathrm{FB}}=30 \mathrm{~Hz}\right)$. FT-IR $\left(\mathrm{ATR}, \mathrm{cm}^{-1}\right): 3033,2916,2858,1909,1605,1506$, $1504,1414,1377,1350,1317,1302 . \mathrm{UV}$-vis (toluene): $\lambda_{\max }=317 \mathrm{~nm}\left(\varepsilon=21900 \mathrm{M}^{-1} \mathrm{~cm}^{-1}\right), 532$ $\mathrm{nm}\left(\varepsilon=20200 \mathrm{M}^{-1} \mathrm{~cm}^{-1}\right)$. ESI-HRMS (+ve mode): calculated for $\left[\mathrm{C}_{22} \mathrm{H}_{21} \mathrm{BF}_{2} \mathrm{~N}_{4}\right]^{+}: 390.1827$, found 390.1841, difference: $+3.6 \mathrm{ppm}$.

Dialkynylborane Complex 10a: Under $\mathrm{N}_{2}$, phenylacetylene $(0.13 \mathrm{~mL}, 1.1 \mathrm{mmol})$ was dissolved in dry THF $(5 \mathrm{~mL})$ in a greaseless Schlenk flask, cooled to $-78{ }^{\circ} \mathrm{C}$, and stirred for $30 \mathrm{~min} . n$ BuLi (1.6 M, $0.45 \mathrm{~mL}, 1.1 \mathrm{mmol})$ was added dropwise over $5 \mathrm{~min}$ and the solution was stirred for $1 \mathrm{~h}$. The solution was then brought to room temperature, stirred for $30 \mathrm{~min}$, and added dropwise to a second greaseless Schlenk flask containing $\mathrm{BF}_{2}$ complex 9 (0.20 g, $\left.0.50 \mathrm{mmol}\right)$ 
dissolved in THF $(10 \mathrm{~mL})$. The solution was stirred for $2 \mathrm{~h}$ at room temperature and gradually changed color from deep purple to red/orange. The solution was then quenched with deionized $\mathrm{H}_{2} \mathrm{O}(7 \mathrm{~mL})$, extracted with $\mathrm{Et}_{2} \mathrm{O}$ that was subsequently washed with deionized $\mathrm{H}_{2} \mathrm{O}(3 \times 50 \mathrm{~mL})$, dried over $\mathrm{MgSO}_{4}$, gravity filtered and concentrated in vacuo. The resulting residue was purified by flash chromatography (2:1 hexanes: $\mathrm{CH}_{2} \mathrm{Cl}_{2}$, silica gel) to afford complex 10a as a red/orange microcrystalline solid after solvent removal in vacuo. Yield $=0.10 \mathrm{~g}(35 \%)$. M.p. $153-155{ }^{\circ} \mathrm{C}$. ${ }^{1} \mathrm{H}$ NMR (599.5 MHz, $\left.\mathrm{CDCl}_{3}\right): \delta 8.02-7.99(\mathrm{~m}, 2 \mathrm{H}$, Aryl $\mathrm{CH}), 7.91-7.88(\mathrm{~m}, 4 \mathrm{H}$, Aryl $\mathrm{CH}$ ), 7.28-7.19 (m, 16H, Aryl $\mathrm{CH}$ ), $2.43\left(\mathrm{~s}, 3 \mathrm{H}, \mathrm{CH}_{3}\right), 2.42\left(\mathrm{~s}, 6 \mathrm{H}, \mathrm{CH}_{3}\right) .{ }^{11} \mathrm{~B}$ NMR $(128.3 \mathrm{MHz}$, $\left.\mathrm{CDCl}_{3}\right): \delta-11.8$ (s). ${ }^{13} \mathrm{C}\left\{{ }^{1} \mathrm{H}\right\} \operatorname{NMR}\left(101.6 \mathrm{MHz}, \mathrm{CDCl}_{3}\right): \delta 151.7,143.3,139.4,138.7,131.5$, 131.3, 129.3, 128.5, 127.9, 127.5, 125.5, 125.2, 124.4, 99.9, 77.2, 21.38, 21.35. FT-IR (ATR, $\left.\mathrm{cm}^{-1}\right): 3030,2952,2920,2854,2367,2341,2187,1598,1491,1489,1442,1350,1280$. UV-vis (toluene): $\lambda_{\max }=320 \mathrm{~nm}\left(\varepsilon=25700 \mathrm{M}^{-1} \mathrm{~cm}^{-1}\right), 521 \mathrm{~nm}\left(\varepsilon=12000 \mathrm{M}^{-1} \mathrm{~cm}^{-1}\right)$. ESI-HRMS (+ve mode): calculated for $\left[\mathrm{C}_{38} \mathrm{H}_{31} \mathrm{BN}_{4}\right]^{+}: 554.2642$, found 554.2651, difference: $+1.6 \mathrm{ppm}$.

Dialkynylborane Complex 10b: Under $\mathrm{N}_{2}$, 4-methoxyphenylacetylene $(0.22 \mathrm{~g}, 1.7 \mathrm{mmol})$ was dissolved in dry THF $(5 \mathrm{~mL})$ in a greaseless Schlenk flask, cooled to $-78{ }^{\circ} \mathrm{C}$, and stirred for 30 min. $n$-BuLi (1.6 M, $0.68 \mathrm{~mL}, 1.7 \mathrm{mmol})$ was added dropwise over 5 min and the solution was stirred for $1 \mathrm{~h}$. The solution was then brought to room temperature and slowly changed from clear yellow to an opaque coffee-brown color. The solution was stirred for $30 \mathrm{~min}$, added dropwise to a second greaseless Schlenk flask containing $\mathrm{BF}_{2}$ complex $9(0.30 \mathrm{~g}, 0.8 \mathrm{mmol})$ dissolved in THF $(10 \mathrm{~mL})$ and stirred for an additional $2 \mathrm{~h}$. The resulting solution gradually changed from deep purple to red and finally brown. The solution was then quenched with deionized $\mathrm{H}_{2} \mathrm{O}(7 \mathrm{~mL})$, extracted with $\mathrm{Et}_{2} \mathrm{O}$ that was subsequently washed with deionized $\mathrm{H}_{2} \mathrm{O}$ (3 $\times 50 \mathrm{~mL}$ ), dried over $\mathrm{MgSO}_{4}$, gravity filtered and concentrated in vacuo. The resulting residue 
was purified by flash chromatography (toluene, silica gel) to afford complex $\mathbf{1 0 b}$ as a red/brown microcrystalline solid after solvent removal in vacuo. Yield $=0.08 \mathrm{~g}(17 \%)$. M.p. $152-154{ }^{\circ} \mathrm{C}$. ${ }^{1} \mathrm{H}$ NMR (399.8 MHz, $\left.\mathrm{CDCl}_{3}\right): \delta$ 8.02-7.98 (m, 2H, Aryl CH), 7.91-7.86 (m, 4H, Aryl CH), 7.28-7.26 (m, 2H, Aryl CH), 7.23-7.21(m, 4H, Aryl CH), 7.17-7.15 (m, 4H, Aryl CH), 6.73$6.71(\mathrm{~m}, 4 \mathrm{H}$, Aryl $\mathrm{CH}), 3.76\left(\mathrm{~s}, 6 \mathrm{H}, \mathrm{OCH}_{3}\right), 2.42\left(\mathrm{~s}, 3 \mathrm{H}, \mathrm{CH}_{3}\right), 2.41\left(\mathrm{~s}, 6 \mathrm{H}, \mathrm{CH}_{3}\right) .{ }^{11} \mathrm{~B}$ NMR (128.3 MHz, $\left.\mathrm{CDCl}_{3}\right): \delta-11.8(\mathrm{~s}) .{ }^{13} \mathrm{C}\left\{{ }^{1} \mathrm{H}\right\} \operatorname{NMR}\left(101.6 \mathrm{MHz}, \mathrm{CDCl}_{3}\right): \delta$ 159.0, 151.7, 143.3, 139.2, 138.7, 132.9, 131.4, 129.2, 128.4, 125.6, 125.2, 116.8, 113.5, 99.7, 77.2, 55.2, 21.38, 21.35. FT-IR (ATR, $\mathrm{cm}^{-1}$ ): 3038, 2956, 2926, 2854, 2189, 1605, 1508, 1464, 1441, 1355, 1282. UV-vis (toluene): $\lambda_{\max }=317 \mathrm{~nm}\left(\varepsilon=23400 \mathrm{M}^{-1} \mathrm{~cm}^{-1}\right), 519 \mathrm{~nm}\left(\varepsilon=12500 \mathrm{M}^{-1} \mathrm{~cm}^{-1}\right)$. ESIHRMS (+ve mode): calculated for $\left[\mathrm{C}_{40} \mathrm{H}_{35} \mathrm{BN}_{4} \mathrm{O}_{2}\right]^{+}: 614.2853$, found 614.2879 , difference: +4.2 ppm.

Dialkynylborane Complex 10c: Under $\mathrm{N}_{2}$, 4-trifluoromethylphenylacetylene $(0.28 \mathrm{~mL}$, $1.7 \mathrm{mmol})$ was dissolved in dry THF $(5 \mathrm{~mL})$ in a greaseless Schlenk flask, cooled to $-78{ }^{\circ} \mathrm{C}$, and stirred for $30 \mathrm{~min} . n$-BuLi (1.6 M, $0.68 \mathrm{~mL}, 1.7 \mathrm{mmol})$ was added dropwise over $5 \mathrm{~min}$ and the solution was stirred for $1 \mathrm{~h}$. While stirring, the solution changed from clear yellow to cloudy white. The solution was held at $-78^{\circ} \mathrm{C}$ and then added dropwise to a second greaseless Schlenk flask containing $\mathrm{BF}_{2}$ complex $9(0.3 \mathrm{~g}, 0.8 \mathrm{mmol})$ dissolved in $\mathrm{THF}(10 \mathrm{~mL})$ at $-78{ }^{\circ} \mathrm{C}$. The deep purple solution slowly turned orange/brown as the solution was brought from $-78{ }^{\circ} \mathrm{C}$ to room temperature and stirred for $2 \mathrm{~h}$. The solution was then quenched with deionized $\mathrm{H}_{2} \mathrm{O}(7 \mathrm{~mL})$, extracted with $\mathrm{Et}_{2} \mathrm{O}$ that was subsequently washed with deionized $\mathrm{H}_{2} \mathrm{O}(3 \times 50 \mathrm{~mL})$, dried over $\mathrm{MgSO}_{4}$, gravity filtered and concentrated in vacuo. The resulting residue was purified by flash chromatography (silica gel). The column was first flushed with hexanes $(50 \mathrm{~mL})$ to remove impurities, followed by toluene $(50 \mathrm{~mL})$ to afford complex 10c as a purple/brown 
microcrystalline solid after solvent removal in vacuo. Yield $=0.09$ g (17\%). M.p. $155-157{ }^{\circ} \mathrm{C}$. ${ }^{1} \mathrm{H}$ NMR (399.8 MHz, $\left.\mathrm{CDCl}_{3}\right): \delta 8.02-7.98(\mathrm{~m}, 2 \mathrm{H}$, Aryl $\mathrm{CH}), 7.87-7.83(\mathrm{~m}, 4 \mathrm{H}$, Aryl $\mathrm{CH}$ ), 7.48-7.44 (m, 4H, Aryl CH), 7.32-7.24 (m, 10H, Aryl CH), $2.43\left(\mathrm{~m}, 9 \mathrm{H}, \mathrm{CH}_{3}\right) .{ }^{11} \mathrm{~B}$ NMR (128.3 MHz, $\left.\mathrm{CDCl}_{3}\right): \delta-12.0(\mathrm{~s}) .{ }^{13} \mathrm{C}\left\{{ }^{1} \mathrm{H}\right\} \operatorname{NMR}\left(101.6 \mathrm{MHz}, \mathrm{CDCl}_{3}\right): \delta 152.1,143.1,139.7$, $139.1,131.7,130.9,129.5,129.4,129.2,128.6,127.9,125.5,125.2,124.9\left(\mathrm{q},{ }^{1} J_{\mathrm{CF}}=16 \mathrm{~Hz}\right)$, 122.6, 98.6, 77.2, 21.38, 21.36. ${ }^{19} \mathrm{~F}$ NMR $\left(376.1 \mathrm{MHz}, \mathrm{CDCl}_{3}\right) \delta-62.8$ (s). FT-IR (ATR, $\left.\mathrm{cm}^{-1}\right)$ : 3043, 2976, 2926, 2872, 2188, 1926, 1615, 1506, 1405, 1320, 1278, 1263. UV-vis (toluene): $\lambda_{\max }=317 \mathrm{~nm}\left(\varepsilon=24900 \mathrm{M}^{-1} \mathrm{~cm}^{-1}\right), 521 \mathrm{~nm}\left(\varepsilon=13700 \mathrm{M}^{-1} \mathrm{~cm}^{-1}\right)$. ESI-HRMS (+ve mode): calculated for $\left[\mathrm{C}_{40} \mathrm{H}_{29} \mathrm{BF}_{6} \mathrm{~N}_{4}\right]^{+}: 690.2389$, found 690.2403 , difference: $+2.0 \mathrm{ppm}$.

Dialkynylborane Complex 10d: Under $\mathrm{N}_{2}$, ethynylferrocene $(0.36 \mathrm{~g}, 1.7 \mathrm{mmol})$ was dissolved in dry THF (5 mL) in a greaseless Schlenk flask, cooled to $-78{ }^{\circ} \mathrm{C}$ and stirred for $30 \mathrm{~min} . n$-BuLi (0.68 $\mathrm{mL}, 1.7 \mathrm{mmol}$ ) was added dropwise over $5 \mathrm{~min}$ and the solution was stirred for $1 \mathrm{~h}$. The solution was then brought to room temperature and stirred for 30 min before it was added dropwise to a second greaseless Schlenk flask containing $\mathrm{BF}_{2}$ complex $9(0.31 \mathrm{~g}, 0.79 \mathrm{mmol})$ dissolved in THF $(10 \mathrm{~mL})$. The solution was then stirred at room temperature for $2 \mathrm{~h}$ and quenched with deionized $\mathrm{H}_{2} \mathrm{O}(7 \mathrm{~mL})$, the organics were extracted with $\mathrm{Et}_{2} \mathrm{O}$ that was subsequently washed with deionized $\mathrm{H}_{2} \mathrm{O}(3 \times 50 \mathrm{~mL})$, dried over $\mathrm{MgSO}_{4}$, gravity filtered and concentrated in vacuo. The resulting residue was purified by flash chromatography (silica gel). The column was first flushed with hexanes $(150 \mathrm{~mL})$ to remove impurities, followed by toluene $(50 \mathrm{~mL})$ to afford the resulting complex $10 \mathrm{~d}$ as a red/orange microcrystalline solid after solvent removal in vacuo. Yield $=0.12 \mathrm{~g}(19 \%)$. M.p. $202-204{ }^{\circ} \mathrm{C} .{ }^{1} \mathrm{H}$ NMR $\left(399.8 \mathrm{MHz}, \mathrm{CDCl}_{3}\right): \delta$ 8.06-8.02 (m, 2H, Aryl CH), 7.91-7.86 (m, 4H, Aryl CH), 7.30-7.26 (m, 6H, Aryl CH), $4.22(\mathrm{t}$, $4 \mathrm{H}, J_{H H}=4 \mathrm{~Hz}$, Aryl CH), $4.05\left(\mathrm{t}, 4 \mathrm{H}, J_{H H}=4 \mathrm{~Hz}\right.$, Aryl CH), $3.92(\mathrm{~s}, 10 \mathrm{H}$, Aryl CH), $2.42(\mathrm{~s}$, 
9H, $\left.\mathrm{CH}_{3}\right) .{ }^{11} \mathrm{~B}$ NMR $\left(128.3 \mathrm{MHz}, \mathrm{CDCl}_{3}\right): \delta-11.8(\mathrm{~s}) .{ }^{13} \mathrm{C}\left\{{ }^{1} \mathrm{H}\right\}$ NMR $\left(101.6 \mathrm{MHz}, \mathrm{CDCl}_{3}\right): \delta$ $151.8,143.4,139.2,138.7,131.4,129.3,128.4,125.6,125.1,98.2,77.2,71.2,69.6,68.0,66.6$, 21.39, 21.36. FT-IR (ATR, $\mathrm{cm}^{-1}$ ): 3093, 3037, 2957, 2923, 2854, 2358, 2189, 1739, 1605, 1506, $1456,1353,1282,1263 . \mathrm{UV}$-vis (toluene): $\lambda_{\max }=317 \mathrm{~nm}\left(\varepsilon=13400 \mathrm{M}^{-1} \mathrm{~cm}^{-1}\right), 517 \mathrm{~nm}(\varepsilon=$ $6800 \mathrm{M}^{-1} \mathrm{~cm}^{-1}$ ). ESI-HRMS (+ve mode): calculated for $\left[\mathrm{C}_{46} \mathrm{H}_{39} \mathrm{BFe}_{2} \mathrm{~N}_{4}\right]^{+}$: 770.1967 , found 770.1977, difference: +1.3 ppm.

Dialkynylborane Complex 10e: Under $\mathrm{N}_{2}$, trimethylsilylacetylene $(0.27 \mathrm{~mL}, 1.9 \mathrm{mmol})$ was dissolved in dry THF $(5 \mathrm{~mL})$ in a greaseless Schlenk flask, cooled to $-78{ }^{\circ} \mathrm{C}$ and stirred for 30 min. $n$-BuLi $(0.79 \mathrm{~mL}, 1.9 \mathrm{mmol})$ was added dropwise over 5 min and the solution was stirred for $1 \mathrm{~h}$. The solution was held at $-78{ }^{\circ} \mathrm{C}$ and then added dropwise to a second greaseless Schlenk flask containing $\mathrm{BF}_{2}$ complex $9(0.35 \mathrm{~g}, 0.90 \mathrm{mmol})$ dissolved in THF $(10 \mathrm{~mL})$ at $-78{ }^{\circ} \mathrm{C}$. The deep purple solution slowly turned red/orange as the solution was warmed from $-78{ }^{\circ} \mathrm{C}$ to room temperature and stirred for $3 \mathrm{~h}$. The solution was then quenched with deionized $\mathrm{H}_{2} \mathrm{O}(7 \mathrm{~mL})$, the organics were extracted with $\mathrm{Et}_{2} \mathrm{O}$ that was subsequently washed with deionized $\mathrm{H}_{2} \mathrm{O}(3 \times 50 \mathrm{~mL})$, dried over $\mathrm{MgSO}_{4}$, gravity filtered and concentrated in vacuo. The resulting residue was purified by flash chromatography (toluene, silica gel) to afford the resulting complex 10e as a purple/brown greasy solid after solvent removal in vacuo. Yield $=0.15 \mathrm{~g}(31 \%) .{ }^{1} \mathrm{H}$ NMR (399.8 MHz, $\left.\mathrm{CDCl}_{3}\right): \delta$ 7.94-7.90 (m, 2H, Aryl CH), 7.78-7.74 (m, 4H, Aryl CH), 7.27$7.22\left(\mathrm{~m}, 2 \mathrm{H}\right.$, Aryl CH), 7.19-7.15 (m, 4H, Aryl CH), $2.41\left(\mathrm{~s}, 3 \mathrm{H}, \mathrm{CH}_{3}\right), 2.38\left(\mathrm{~s}, 6 \mathrm{H}, \mathrm{CH}_{3}\right),-0.05$ (s, $\left.18 \mathrm{H}, \mathrm{CH}_{3}\right) .{ }^{11} \mathrm{~B}$ NMR $\left(128.3 \mathrm{MHz}, \mathrm{CDCl}_{3}\right): \delta-13.2(\mathrm{~s}) .{ }^{13} \mathrm{C}\left\{{ }^{1} \mathrm{H}\right\}$ NMR (101.6 MHz, $\left.\mathrm{CDCl}_{3}\right)$ : $\delta 152.6,142.8,139.2,138.8,131.0,129.1,128.3,125.7,125.3,106.8,77.2,21.4,21.3,-0.3$. FTIR (ATR, $\mathrm{cm}^{-1}$ ): 3035, 2957, 2923, 2897, 2857, 2132, 1605, 1505, 1351, 1260, 1247, 1209. UV- 
vis (toluene): $\lambda_{\max }=317 \mathrm{~nm}\left(\varepsilon=25100 \mathrm{M}^{-1} \mathrm{~cm}^{-1}\right), 515 \mathrm{~nm}\left(\varepsilon=14200 \mathrm{M}^{-1} \mathrm{~cm}^{-1}\right)$. ESI-HRMS (+ve mode): calculated for $\left[\mathrm{C}_{32} \mathrm{H}_{39} \mathrm{BN}_{4} \mathrm{Si}_{2}\right]^{+}: 546.2806$, found 546.2770, difference: $-6.6 \mathrm{ppm}$.

Radical anion 10a ${ }^{--}$: In a $\mathrm{N}_{2}$ filled glovebox, complex 10a $(0.29 \mathrm{~g}, 0.51 \mathrm{mmol})$ was dissolved in toluene $(15 \mathrm{~mL})$ and stirred for $15 \mathrm{~min}$. Separately, bis(cyclopentadienyl)cobalt (II) $(0.10 \mathrm{~g}$, $0.51 \mathrm{mmol})$ was dissolved in toluene $(6 \mathrm{~mL})$ and stirred for $15 \mathrm{~min}$. The solution was then added dropwise to the solution of $\mathbf{1 0 a}$ and stirred for $4 \mathrm{~h}$. The resulting brown/green suspension was then vacuum filtered and the solid was washed with toluene $(5 \mathrm{~mL})$ followed by pentane $(10 \mathrm{~mL})$ to afford $10 \mathrm{a}^{-}$as a green powder. Yield $=0.31 \mathrm{~g}(81 \%)$. M.p. $200-202{ }^{\circ} \mathrm{C}$. FT-IR (ATR, $\left.\mathrm{cm}^{-1}\right): 3098,3015,2919,2858,1500,1485,1415,1327,1278,1260 . \mathrm{UV}$-vis $\left(\mathrm{CH}_{3} \mathrm{CN}\right): \lambda_{\max }=$ $260 \mathrm{~nm}\left(\varepsilon=70400 \mathrm{M}^{-1} \mathrm{~cm}^{-1}\right), 308 \mathrm{~nm}\left(\varepsilon=23300 \mathrm{M}^{-1} \mathrm{~cm}^{-1}\right), 465 \mathrm{~nm}\left(\varepsilon=11900 \mathrm{M}^{-1} \mathrm{~cm}^{-1}\right)$, $787 \mathrm{~nm}\left(\varepsilon=3800 \mathrm{M}^{-1} \mathrm{~cm}^{-1}\right), 826 \mathrm{~nm}\left(\varepsilon=3450 \mathrm{M}^{-1} \mathrm{~cm}^{-1}\right)$. ESI-HRMS (-ve mode): calculated for $\left[\mathrm{C}_{38} \mathrm{H}_{31} \mathrm{BN}_{4}\right]^{-}: 554.2647$, found 554.2642, difference: $-0.9 \mathrm{ppm}$.

Radical anion 10d ${ }^{-}$: In an $\mathrm{N}_{2}$ filled glovebox, complex $10 d(0.18 \mathrm{~g}, 0.23 \mathrm{mmol})$ was dissolved in toluene $(15 \mathrm{~mL})$ and stirred for 15 min. Separately, bis(pentamethylcyclopentadienyl)cobalt(II) $(0.075 \mathrm{~g}, 0.23 \mathrm{mmol})$ was dissolved in toluene $(6 \mathrm{~mL})$ and stirred for $15 \mathrm{~min}$. This solution was then added dropwise to the solution of $\mathbf{1 0 d}$ and stirred for $4 \mathrm{~h}$. The resulting emerald green suspension was then vacuum filtered and the solid was washed with toluene $(5 \mathrm{~mL})$ followed by pentane $(10 \mathrm{~mL})$ to afford $\mathbf{1 0 d}^{-}$as a microcrystalline green powder. Yield $=0.27 \mathrm{~g}(89 \%)$. M.p. $171-173^{\circ} \mathrm{C}($ decomp.). FT-IR (ATR, $\left.\mathrm{cm}^{-1}\right)$ : 3096, 3078, 3021, 2991, 2958, 2916, 2853, 2156, 1716, 1602, 1501, 1374, 1334. UV-vis $\left(\mathrm{CH}_{3} \mathrm{CN}\right): \lambda_{\max }=294 \mathrm{~nm}\left(\varepsilon=43450 \mathrm{M}^{-1} \mathrm{~cm}^{-1}\right), 470 \mathrm{~nm}\left(\varepsilon=9600 \mathrm{M}^{-1} \mathrm{~cm}^{-1}\right), 767 \mathrm{~nm}(\varepsilon=$ $\left.2700 \mathrm{M}^{-1} \mathrm{~cm}^{-1}\right), 833 \mathrm{~nm}\left(\varepsilon=2350 \mathrm{M}^{-1} \mathrm{~cm}^{-1}\right)$. ESI-HRMS (-ve mode): calculated for $\left[\mathrm{C}_{46} \mathrm{H}_{39} \mathrm{BFe}_{2} \mathrm{~N}_{4}\right]^{-}:$770.1972, found 770.1967, difference: $-0.6 \mathrm{ppm}$. 
Dialkynylborane Complex 11: In air, complex 10e $(0.41 \mathrm{~g}, 0.74 \mathrm{mmol})$ was dissolved in warm $\mathrm{MeOH}(50 \mathrm{~mL}) \cdot \mathrm{K}_{2} \mathrm{CO}_{3}(1.5 \mathrm{~g}, 11 \mathrm{mmol})$ was added and the solution was stirred at room temperature for $4 \mathrm{~h}$. The solution was then concentrated in vacuo and the resulting residue was extracted with $\mathrm{Et}_{2} \mathrm{O}$ and deionized $\mathrm{H}_{2} \mathrm{O}(3 \times 50 \mathrm{~mL})$, dried over $\mathrm{MgSO}_{4}$, gravity filtered and concentrated in vacuo. The resulting residue was purified by flash chromatography (1:1 hexanes: $\mathrm{CH}_{2} \mathrm{Cl}_{2}$, silica gel) to afford the resulting complex $\mathbf{1 1}$ as a purple microcrystalline solid after solvent removal in vacuo. Yield $=0.25 \mathrm{~g}(84 \%)$. M.p. $146-148{ }^{\circ} \mathrm{C} .{ }^{1} \mathrm{H}$ NMR $(399.8 \mathrm{MHz}$, $\left.\mathrm{CDCl}_{3}\right): \delta$ 7.98-7.94 (m, 2H, Aryl CH), 7.77-7.73 (m, 4H, Aryl CH), 7.29-7.25 (m, 2H, Aryl $\mathrm{CH}), 7.24-7.20(\mathrm{~m}, 4 \mathrm{H}$, Aryl $\mathrm{CH}), 2.41\left(\mathrm{~s}, 3 \mathrm{H}, \mathrm{CH}_{3}\right), 2.40\left(\mathrm{~s}, 6 \mathrm{H}, \mathrm{CH}_{3}\right), 2.22(\mathrm{~s}, 2 \mathrm{H}$, Alkyne $\mathrm{CH})$. ${ }^{11} \mathrm{~B}$ NMR (128.3 MHz, $\left.\mathrm{CDCl}_{3}\right): \delta-13.3(\mathrm{~s}) .{ }^{13} \mathrm{C}\left\{{ }^{1} \mathrm{H}\right\} \mathrm{NMR}\left(101.6 \mathrm{MHz}, \mathrm{CDCl}_{3}\right): \delta 151.6,143.0$, 139.6, 139.0, 130.9, 129.3, 128.6, 125.5, 125.1, 88.1, 77.2, 21.4, 21.3. FT-IR (ATR, $\left.\mathrm{cm}^{-1}\right): 3281$, $3031,2921,2060,1606,1506,1353,1281,1264,1177$. UV-vis (toluene): $\lambda_{\max }=317 \mathrm{~nm}(\varepsilon=$ $\left.24200 \mathrm{M}^{-1} \mathrm{~cm}^{-1}\right), 524 \mathrm{~nm}\left(\varepsilon=14400 \mathrm{M}^{-1} \mathrm{~cm}^{-1}\right)$. ESI-HRMS (+ve mode): calculated for $\left[\mathrm{C}_{26} \mathrm{H}_{23} \mathrm{BN}_{4}\right]^{+}:$402.2016, found 402.2017, difference: $+0.2 \mathrm{ppm}$.

Bis(triazolyl)borane Complex 12: Under $\mathrm{N}_{2}, N, N, N^{\prime}, N^{\prime \prime}, N^{\prime \prime}$-pentamethyldiethylenetriamine $(3 \mu \mathrm{L}, 0.02 \mathrm{mmol})$ and $\mathrm{CuI}(0.003 \mathrm{~g}, 0.02 \mathrm{mmol})$ were dissolved in dry THF $(3 \mathrm{~mL})$ and stirred for $30 \mathrm{~min}$. The solution gradually changed from clear to pale yellow. Benzyl azide (58 $\mu \mathrm{L}$, $0.50 \mathrm{mmol})$ was added dropwise followed by complex $11(0.062 \mathrm{~g}, 0.2 \mathrm{mmol})$. The resulting purple solution was diluted with THF $(7 \mathrm{~mL})$ and stirred at $45^{\circ} \mathrm{C}$ for $18 \mathrm{~h}$. The solution was then cooled to room temperature, gravity filtered and the supernatant concentrated in vacuo. The resulting residue was purified by flash chromatography $\left(\mathrm{CH}_{2} \mathrm{Cl}_{2}\right.$, silica gel) to afford complex 12 as a purple microcrystalline solid after solvent removal in vacuo. Yield $=0.050 \mathrm{~g}(38 \%)$. M.p. 169-171 ${ }^{\circ} \mathrm{C} .{ }^{1} \mathrm{H}$ NMR $\left(399.8 \mathrm{MHz}, \mathrm{CDCl}_{3}\right): \delta 8.06-8.03$ (m, 2H, Aryl $\left.\mathrm{CH}\right), 7.37-7.35(\mathrm{~m}, 6 \mathrm{H}$, 
Aryl $\mathrm{CH}$ ), $7.31\left(\mathrm{~d}, 2 \mathrm{H}, J_{H H}=8 \mathrm{~Hz}\right.$, Aryl $\left.\mathrm{CH}\right), 7.26-7.24(\mathrm{~m}, 6 \mathrm{H}$, Aryl $\mathrm{CH}$ and triazolyl $\mathrm{CH})$, 7.08-7.06 (m, 4H, Aryl CH), 6.97-6.94 (m, 4H, Aryl CH), 5.35 (s, 4H, Benzyl CH), 2.44 (s, 3H, $\left.\mathrm{CH}_{3}\right), 2.32$ (s, 6H, $\left.\mathrm{CH}_{3}\right) .{ }^{11} \mathrm{~B} \mathrm{NMR}\left(128.3 \mathrm{MHz}, \mathrm{CDCl}_{3}\right): \delta-6.0(\mathrm{~s}) .{ }^{13} \mathrm{C}\left\{{ }^{1} \mathrm{H}\right\} \mathrm{NMR}(101.6 \mathrm{MHz}$, $\left.\mathrm{CDCl}_{3}\right): \delta 153.8,143.2,139.4,139.2,136.4,135.6,130.7,129.4,129.2,129.1,128.4,125.7$, 125.5, 124.5, 77.2, 52.1, 21.4, 21.2. FT-IR (ATR, $\left.\mathrm{cm}^{-1}\right): 3034,2926,2855,1604,1505,1355$, 1282, 1262, 1211, 954, 821. UV-vis (toluene): $\lambda_{\max }=295 \mathrm{~nm}\left(\varepsilon=29750 \mathrm{M}^{-1} \mathrm{~cm}^{-1}\right), 532 \mathrm{~nm}(\varepsilon=$ $13100 \mathrm{M}^{-1} \mathrm{~cm}^{-1}$ ). ESI-HRMS (+ve mode): calculated for $\left[\mathrm{C}_{40} \mathrm{H}_{37} \mathrm{BN}_{10}\right]^{+}: 668.3296$, found 668.3314, difference: +2.7 ppm.

\section{RESULTS AND DISCUSSION}

\section{Synthesis and X-ray Crystallography}

Formazan 8 was synthesized according to a published procedure ${ }^{70}$ and was converted to the corresponding $\mathrm{BF}_{2}$ formazanate 9 in $86 \%$ yield by heating an excess of $\mathrm{BF}_{3} \cdot \mathrm{OEt}_{2}$ and $\mathrm{NEt}_{3}$ at $80{ }^{\circ} \mathrm{C}$ in toluene under anhydrous conditions for $18 \mathrm{~h}$ (Scheme 1). This transformation was accompanied by a loss of the NH resonance at $15.42 \mathrm{ppm}$ in the ${ }^{1} \mathrm{H}$ NMR spectrum of formazan 8 and the appearance of a triplet at $-0.5 \mathrm{ppm}\left({ }^{1} J_{\mathrm{BF}}=29 \mathrm{~Hz}\right)$ in the ${ }^{11} \mathrm{~B}$ NMR spectrum and a quartet at $-145.0 \mathrm{ppm}\left({ }^{1} J_{\mathrm{FB}}=30 \mathrm{~Hz}\right)$ in the ${ }^{19} \mathrm{~F}$ NMR spectrum of 9 (Figures S1-S3). BF 2 complex 9 was subsequently converted to dialkynylborane complexes $10 \mathbf{a}-10 \mathrm{e}$ by treatment with a slight excess of the lithium salts of a series of substituted alkynes according to Scheme 1. The yields of these reactions, which were generally lower than those observed for the synthesis of related BODIPYs, ${ }^{71}$ reflected the steric congestion at boron imposed by the $\mathrm{N}$-aryl substituents of the formazanate ligand framework and ranged from $17-35 \%$. After workup, the mass balance for these reactions was made up of trace amounts of the parent formazan, which was regenerated 
during the reaction, and other highly colored decomposition products that we have been unable to identify. The degree of decomposition increased when alkynyl lithium reagents were replaced with the corresponding Grignards and the synthetic pathway employed was not compatible with 3-cyanoformazanate complexes due to the apparent reactivity between the carbanions employed and the cyano substituents of the ligand backbone. Despite these considerations, our synthetic approach takes advantage of the ready accessibility of formazans and circumvents many of the challenges associated with BODIPY synthesis. The NMR spectra collected for complexes 10a10e indicated that the $N$-aryl substituents were equivalent on the NMR timescale (Figures S4S19). Notably, the ${ }^{11}$ B NMR spectra for these compounds were comprised of broadened singlets that appeared between -11.8 and $-13.2 \mathrm{ppm}$. The intensity of these resonances was diminished compared to the ${ }^{11} \mathrm{~B}$ NMR resonance observed for 9 due to the decreased Nuclear Overhauser Effect that resulted from the replacement of a fluorine atom with a substituted alkynyl ligand. FT-IR spectroscopy and mass spectrometry data corroborated the proposed structures of complexes 10a-10e.

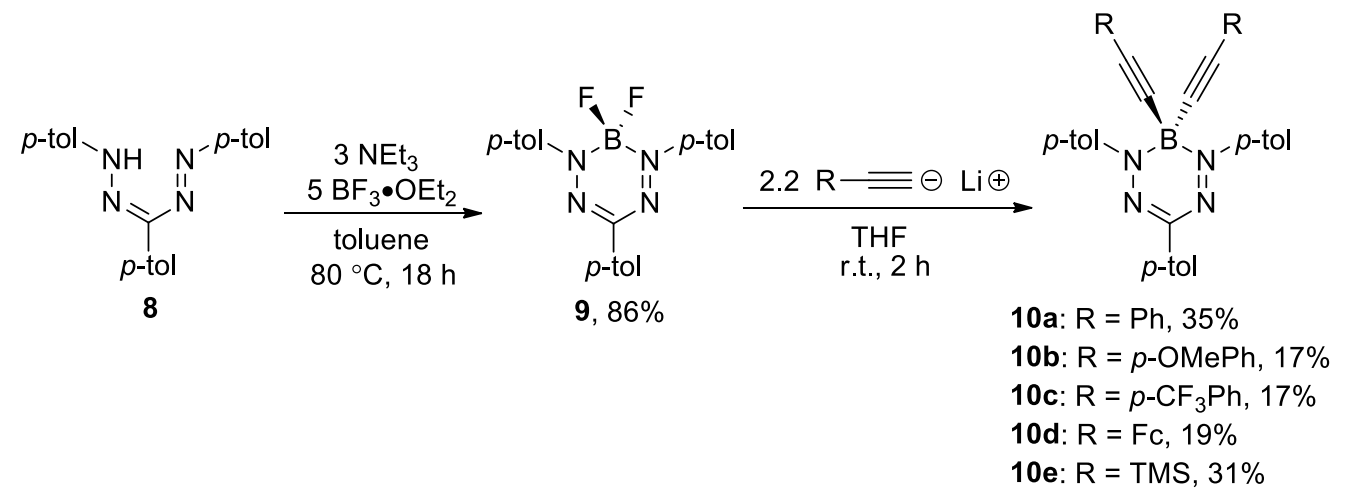

Scheme 1. Synthesis of dialkynylborane complexes 10a-10e.

To gain further insight into the structure and bonding associated with complexes 10a-10e and 9, we employed single-crystal X-ray diffraction measurements (Figure 1, Table 1, Table S1). 
The solid-state structures of complexes $\mathbf{9}, \mathbf{1 0 a}$, and 10d provide an indication that the $\pi$-systems of the formazanate ligand backbones are highly delocalized, with N-N [1.3028(7)-1.316(3) $\mathrm{A}]$ and C-N [1.3385(8)-1.352(2) ̊] bond lengths falling between what would normally be expected for single and double bonds of the same atoms. ${ }^{72}$ The most significant difference in the structures of $10 \mathbf{a}$ and $10 \mathbf{d}$ when compared to that of the $\mathrm{BF}_{2}$ complex 9 is the position of the boron atom relative to the plane defined by the four nitrogen atoms of the formazanate backbone $\left(\mathrm{N}_{4}: \mathrm{N} 1, \mathrm{~N} 2\right.$, $\mathrm{N} 3, \mathrm{~N} 4)$ and the related twisting of the $N$-aryl substituents relative to the same plane. The solidstate structure of $\mathbf{9}$ is highly planar and consistent with most other $\mathrm{BF}_{2}$ formazanates, ${ }^{69}$ with the boron atom sitting $0.094 \AA$ above the $\mathrm{N}_{4}$ plane and average angles between the plane defined by the $N$-aryl substituent and the $\mathrm{N}_{4}$ plane of $6.50^{\circ}$. In contrast, the structure adopted by $10 a$ significantly deviates from planarity. The boron atom is displaced from the $\mathrm{N}_{4}$ plane by $0.713 \AA$ and the average angle between the $\mathrm{N}_{4}$ plane and the $N$-aryl substituents is $57.76^{\circ}$. These metrics are further exaggerated in the solid-structure of 10d, with corresponding values of $0.755 \AA$ and $67.40^{\circ}$. We postulate that the observed conformations are adopted as a result of optimized solidstate packing rather than steric effects implicating the boron- and nitrogen-bound substituents. Similar conformations have been occasionally observed for $\mathrm{BF}_{2}$ formazanates indicating that there is a relatively small energetic penalty associated with deviations from planarity. ${ }^{55}$ Furthermore, low temperature ${ }^{1} \mathrm{H}$ NMR spectra collected for complex 10d did not provide evidence for the presence of inequivalent ferrocene environments that would be expected if a similar conformation existed in solution (Figure S20). 


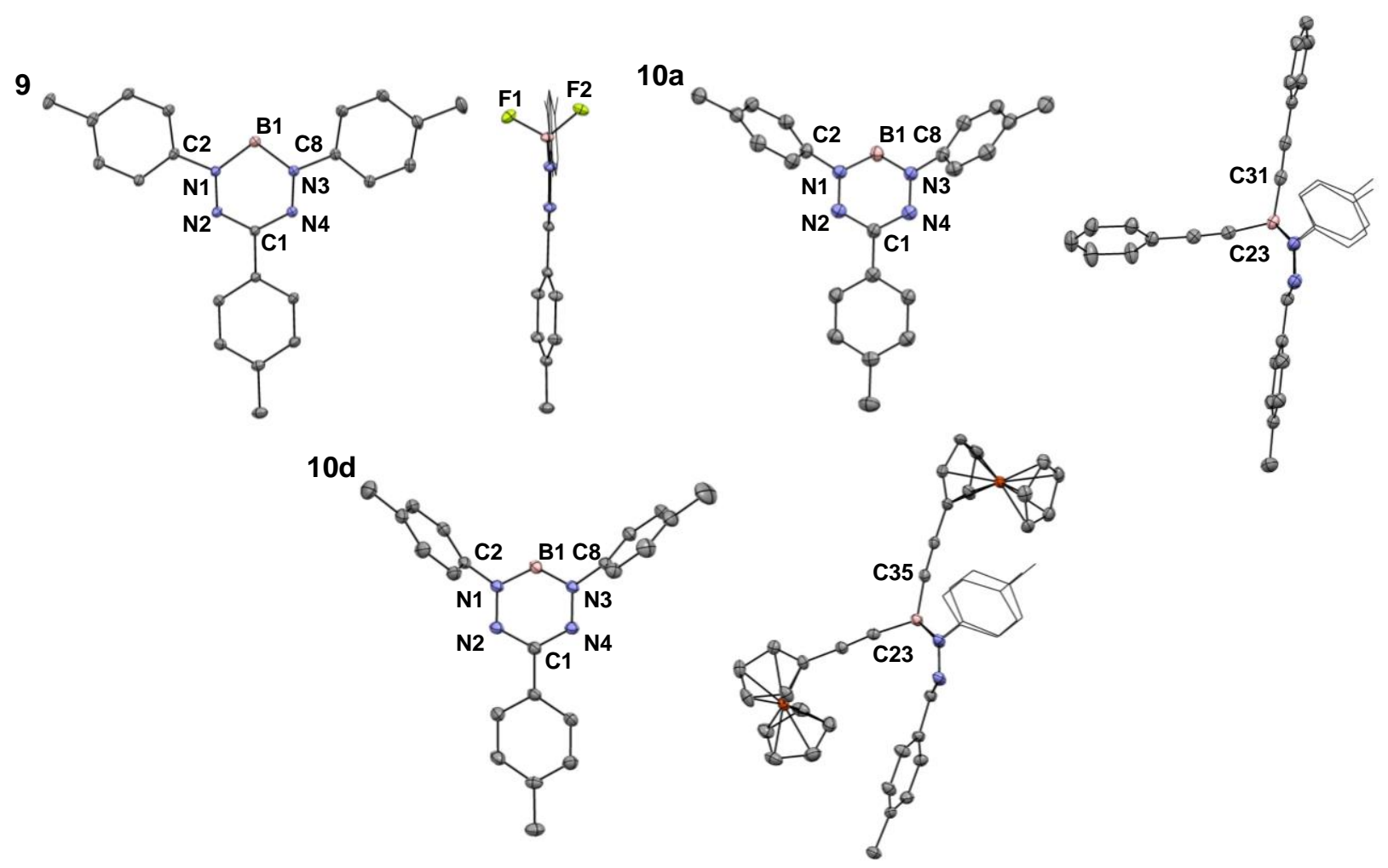

Figure 1. Top and side views of the solid-state structures of compounds 9, 10a, and 10d. Anisotropic displacement ellipsoids are shown at the 50\% probability level. Hydrogen atoms and alkynyl substituents (top view) have been omitted and $N$-aryl substituents (side view) have been displayed in wireframe format for clarity.

Table 1. Selected bond lengths $(\AA)$, bond angles $\left({ }^{\circ}\right)$, and structural metrics extracted from the solid-state structures of compounds $9, \mathbf{1 0 a}$, and $10 \mathrm{~d}$.

\begin{tabular}{llll}
\hline & $\mathbf{9}$ & $\mathbf{1 0 a}$ & $\mathbf{1 0 d}$ \\
\hline B1-N1 & $1.566(1)$ & $1.575(4)$ & $1.576(3)$ \\
B1-N3 & $1.5604(9)$ & $1.573(3)$ & $1.581(3)$ \\
N1-N2 & $1.3037(7)$ & $1.312(3)$ & $1.313(2)$ \\
N3-N4 & $1.3028(7)$ & $1.316(3)$ & $1.308(2)$ \\
C1-N2 & $1.3417(8)$ & $1.346(3)$ & $1.343(2)$ \\
C1-N4 & $1.3385(8)$ & $1.344(3)$ & $1.352(2)$ \\
N1-B1-N3 & $106.10(5)$ & $97.49(2)$ & $96.10(1)$ \\
N2-N1-B1 & $124.66(5)$ & $118.44(2)$ & $117.48(1)$ \\
N4-N3-B1 & $124.17(5)$ & $118.16(2)$ & $118.13(1)$ \\
N2-C1-N4 & $126.46(5)$ & $121.67(2)$ & $120.96(2)$ \\
Dihedral Angles $^{a}$ & $4.51,8.48$ & $54.92,60.60$ & $66.87,67.92$ \\
Boron Displacement $^{b}$ & 0.094 & 0.713 & 0.755 \\
\hline
\end{tabular}

${ }^{a}$ The angle between the planes defined by the $N$-aryl substituents and the $\mathrm{N}_{4}$ plane of the formazanate ligand backbone. ${ }^{b}$ The distance between $\mathrm{B} 1$ and the $\mathrm{N}_{4}$ plane of the formazanate ligand backbone. 


\section{Electronic Properties}

The structural metrics highlighted above have implications on the UV-vis absorption spectra of compounds 9 and 10a-10d (Figure 2 and Table 2). The parent $\mathrm{BF}_{2}$ complex 9 has a low-energy absorption maximum $\left(\lambda_{\max }\right)$ of $532 \mathrm{~nm}$ with a molar absorptivity $(\varepsilon)$ of $20200 \mathrm{M}^{-1}$ $\mathrm{cm}^{-1}$. This transition has previously been demonstrated to be highly dependent on the nature of the $N$-aryl substituents of the formazanate ligand and assigned as a $\pi \rightarrow \pi^{*}$ transition involving primarily the highest occupied molecular orbital (HOMO) and lowest unoccupied molecular orbital (LUMO) orbitals. ${ }^{55}$ Relative to the spectrum obtained for $\mathbf{9}$, this band was blue-shifted and less intense in the spectra obtained for 10a-10d with $\lambda_{\max }$ values ranging from 517 to 521 $\mathrm{nm}$ and $\varepsilon$ values ranging from 6800 to $13700 \mathrm{M}^{-1} \mathrm{~cm}^{-1}$. The absorption maxima associated with the $\pi \rightarrow \pi^{*}$ transition for complexes 10a-10d appeared at energies that were similar to $E$ BODIPYs ${ }^{73}$ and were not solvatochromic. They also showed little to no dependence on the nature of the alkynyl substituent as these substituents lie in a plane that is orthogonal to the formazanate ligand backbone. Complexes 9 and 10a-10d were essentially non-emissive in solution and the solid state with photoluminescence quantum yields less than $1 \%$. 


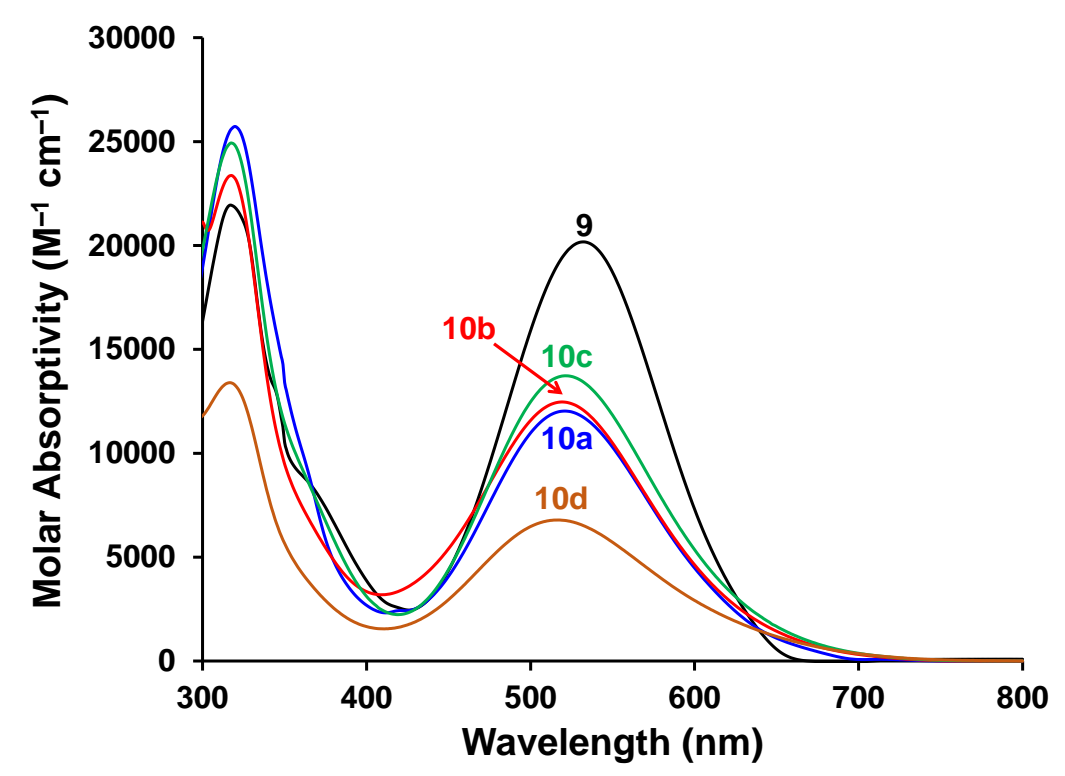

Figure 2. UV-vis absorption spectra of compounds 9 and $\mathbf{1 0 a}-\mathbf{1 0 d}$ recorded for $10 \mu \mathrm{M}$ toluene solutions.

A differentiating feature between borane complexes of formazanates and complexes of most other chelating $N$-donor ligands is their redox activity. In order to probe the redox activity of complexes 9 and 10a-10d, solution phase cyclic voltammetry (CV) was employed (Figure 3, Table 2). Complex 9 was reversibly oxidized to its radical cation $\mathbf{9}^{\circ+}$ at $E_{\text {ox } 1}=1.03 \mathrm{~V}$ relative to the ferrocene/ferrocenium redox couple. Consistent with other $\mathrm{BF}_{2}$ formazanates, it also underwent stepwise one-electron reductions to the corresponding radical anion $\mathbf{9}^{\mathbf{-}}$ and dianion $\mathbf{9}^{2-}$ at potentials of $E_{\text {red } 1}=-1.04 \mathrm{~V}$ and $E_{\text {red } 2}=-1.99 \mathrm{~V} \cdot{ }^{69}$ The second reduction was irreversible under our experimental conditions, likely due to a chemical reaction between the extremely electron-rich dianion and a component of the analyte solution that regenerates the radical anion. The electrochemical properties of 10a-10d, which implicated the species highlighted in Scheme 2, were qualitatively similar. In the case of compounds $\mathbf{1 0 b}-\mathbf{d}$, the first reduction was not formally reversible when the full electrochemical window of the solvent was scanned. However, the first reduction wave became reversible when a narrower potential window that excluded the 
second reduction wave was examined (Figure S21). In all cases the dialkynylborane complexes were easier to oxidize and more difficult to reduce than the corresponding $\mathrm{BF}_{2}$ complex due to the greater electron-donating character of alkynyl substituents compared to the fluorine atoms. Comparison of the CVs of 10a-10c provides an indication of the effect of the substituted alkyne substituents on the electronic structure of the compounds. Complex 10a $(\mathrm{R}=\mathrm{Ph})$ was reduced at potentials of $E_{\text {red } 1}=-1.18 \mathrm{~V}$ and $E_{\text {red } 2}=-2.03 \mathrm{~V}$. The introduction of electron-donating $p$ $\mathrm{OMePh}$ substituents in $\mathbf{1 0 b}$ rendered the complex more difficult to reduce as indicated by the negatively-shifted reduction potentials $E_{\text {red1 }}=-1.21 \mathrm{~V}$ and $E_{\text {red2 }}=-2.12 \mathrm{~V}$. The $p-\mathrm{CF}_{3} \mathrm{Ph}$ substituents of $9 \mathbf{c}$ had the opposite effect, shifting the reduction potentials to more positive values of $E_{\text {red } 1}=-1.14 \mathrm{~V}$ and $E_{\text {red } 2}=-2.01 \mathrm{~V}$. The potentials corresponding to the oxidation of compounds 10a-10c followed a similar trend, although direct comparison was complicated by the irreversibility of the oxidation wave corresponding to complex $10 \mathrm{~b}(\mathrm{R}=p$-OMePh $)$. In addition to the electrochemical features discussed above, complex 10d $(\mathrm{R}=\mathrm{Fc})$ gave rise to a reversible wave, that corresponded to twice the current of the first reduction wave, centered at a potential $E_{\mathrm{Fc} / \mathrm{Fc}+}=0.03 \mathrm{~V}$. This observation is consistent with two coincident (or near coincident) one-electron processes corresponding to the oxidation of two electron-rich ferrocene groups.

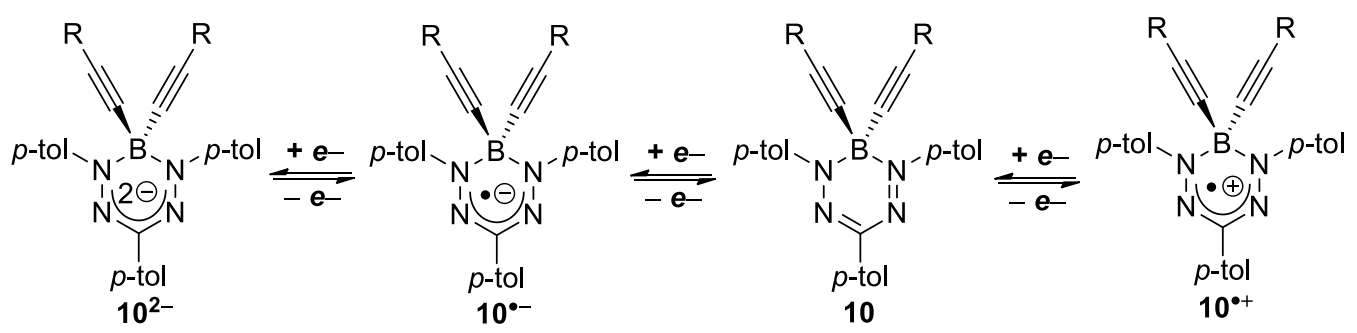

Scheme 2. Electrochemically relevant forms of dialkynylborane formazanate complexes $\mathbf{1 0}$. 


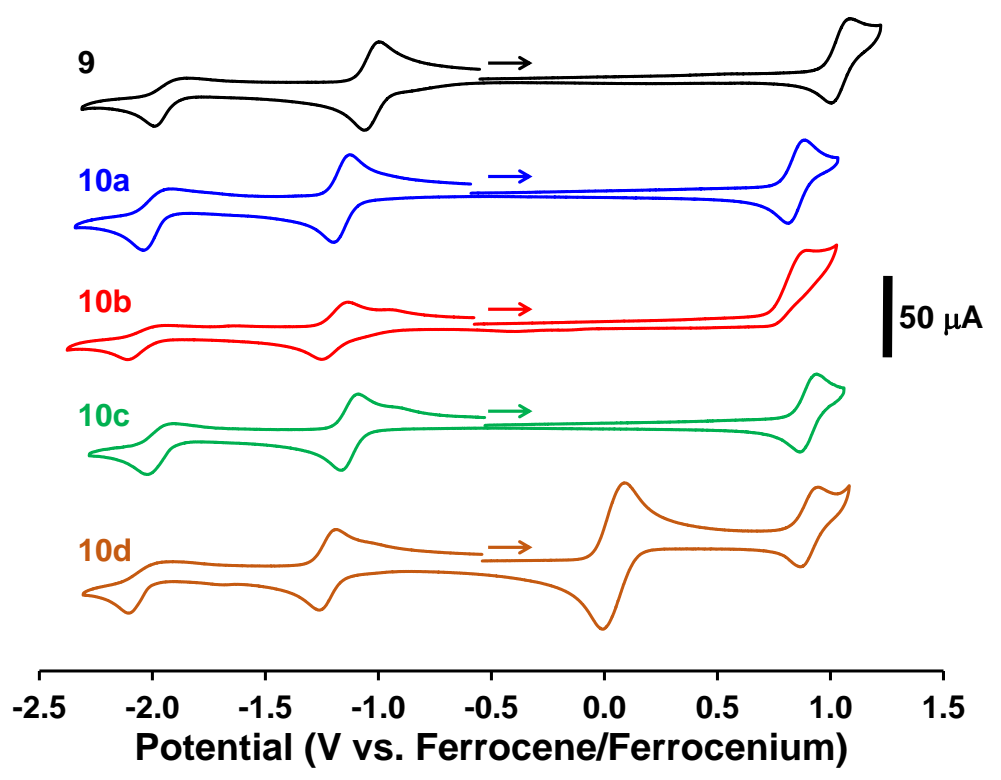

Figure 3. $\mathrm{CV}$ s of compounds 9 and 10a-10d recorded in dry, degassed $\mathrm{CH}_{2} \mathrm{Cl}_{2}$ containing $\sim 1 \mathrm{mM}$ analyte and $0.1 \mathrm{M}\left[n \mathrm{Bu}_{4} \mathrm{~N}\right]\left[\mathrm{PF}_{6}\right]$ as a supporting electrolyte at a scan rate of $250 \mathrm{mV} \mathrm{s}^{-1}$. The arrows indicate the scan direction.

Table 2. Solution-state characterization data for compounds 9 and 10a-10d.

\begin{tabular}{lllllll}
\hline Compound & $\lambda_{\max }(\mathrm{nm})^{a}$ & $\varepsilon\left(\mathrm{M}^{-1} \mathrm{~cm}^{-1}\right)^{a}$ & $E_{\mathrm{red} 2}(\mathrm{~V})^{b}$ & $E_{\mathrm{red} 1}(\mathrm{~V})^{b}$ & $E_{\mathrm{Fc} / \mathrm{Fc}+}(\mathrm{V})^{b}$ & $E_{\mathrm{Ox} 1}(\mathrm{~V})^{b}$ \\
\hline $\mathbf{9}$ & 532 & 20200 & $-1.99^{c}$ & -1.04 & - & 1.03 \\
$\mathbf{1 0 a}$ & 521 & 12000 & $-2.03^{c}$ & -1.18 & - & 0.83 \\
$\mathbf{1 0 b}$ & 519 & 12500 & $-2.12^{c}$ & -1.21 & - & $0.86^{d}$ \\
$\mathbf{1 0 c}$ & 521 & 13700 & $-2.01^{c}$ & -1.14 & - & 0.89 \\
$\mathbf{1 0 d}$ & 517 & 6800 & $-2.09^{c}$ & -1.21 & 0.03 & 0.89 \\
\hline
\end{tabular}

${ }^{a}$ Recorded for $10 \mu \mathrm{M}$ toluene solutions. ${ }^{b} \mathrm{CVs}$ were recorded for dry, degassed $\mathrm{CH}_{2} \mathrm{Cl}_{2}$ solutions containing $\sim 1 \mathrm{mM}$ analyte and $0.1 \mathrm{M}\left[n \mathrm{Bu}_{4} \mathrm{~N}\right]\left[\mathrm{PF}_{6}\right]$ as a supporting electrolyte at a scan rate of $250 \mathrm{mV} \mathrm{s}^{-1}$. Potentials are reported relative to the ferrocene/ferrocenium redox couple. ${ }^{c}$ Irreversible peak. Potential at maximum cathodic current reported. ${ }^{d}$ Irreversible peak. Potential at maximum anodic current reported.

\section{Reactivity}

Given the reversible oxidation and reduction waves observed in the CVs of compounds 10a-10d, we attempted to access the radical cation and radical anion forms of complexes $\mathbf{1 0 a}$ and 10d. However, we were unable to isolate pure oxidation products formed upon treatment of dialkynylborane complexes with a variety of oxidants, including $\left[\left(p-\mathrm{BrC}_{6} \mathrm{H}_{4}\right)_{3} \mathrm{~N}\right]\left[\mathrm{SbCl}_{6}\right]($ magic 
blue), $\mathrm{NOBF}_{4}$, and $\mathrm{WCl}_{6}$. Conversely, radical anions $\mathbf{1 0 a}^{--}$and $\mathbf{1 0 d}^{--}$that were stable enough to be isolated and characterized were produced when 10a and 10d were treated with $\left[\mathrm{Co}\left(\mathrm{C}_{5} \mathrm{H}_{5}\right)_{2}\right]$ and $\left[\mathrm{Co}\left(\mathrm{C}_{5} \mathrm{Me}_{5}\right)_{2}\right]$, respectively (Scheme 3).

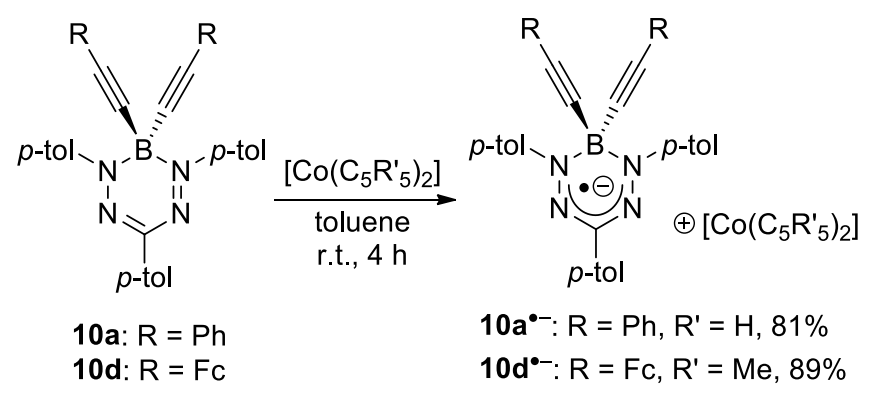

Scheme 3. Chemical reduction of complexes 10a and 10d.

Conversion of 10a and 10d to their radical anion forms was accompanied by a dramatic color change in the isolated products from red/orange to green. Dilute solutions of $\mathbf{1 0 a}^{\mathbf{-}}$ and $\mathbf{1 0 d}^{\circ-}$ yielded isotropic electron paramagnetic resonance (EPR) spectra with $g$-factors of 2.0035 and UV-vis absorption spectra with bands centered at 787 and $826 \mathrm{~nm}$ for $\mathbf{1 0 a}^{-}$and 767 and $833 \mathrm{~nm}$ for $\mathbf{1 0 d}^{--}$(Figure 4 and S22). These spectral features were qualitatively similar to other borataverdazyl-type radicals derived from formazanate ligands. ${ }^{53,74}$ 


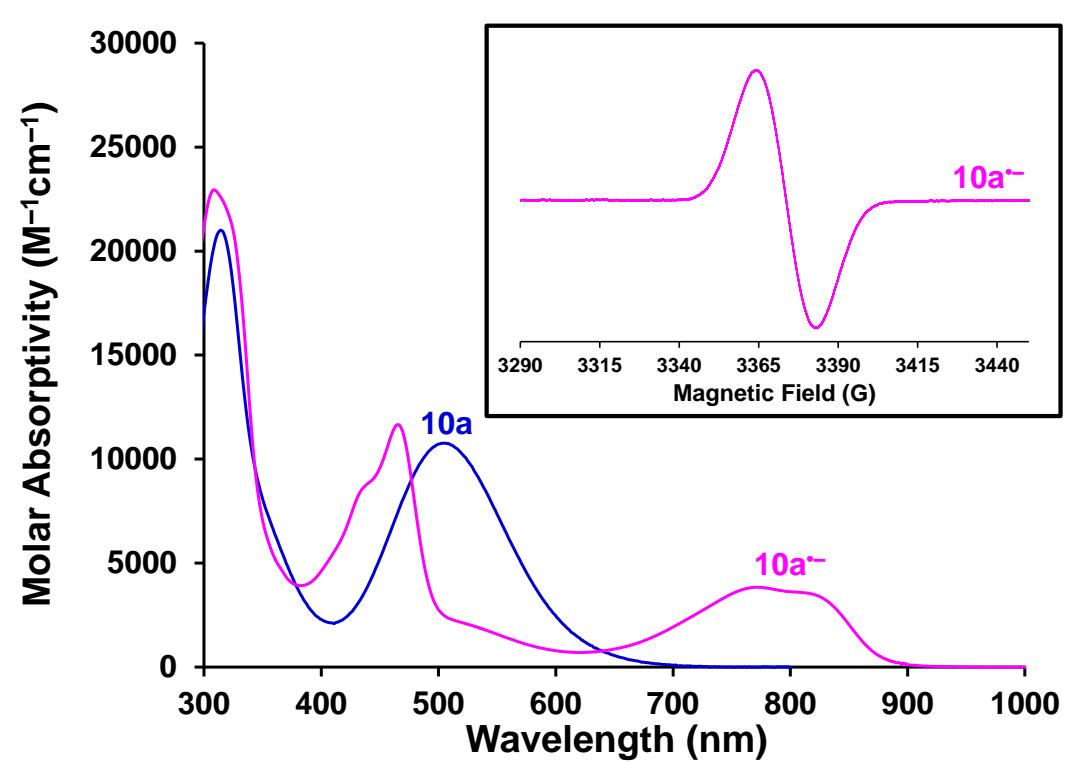

Figure 4. UV-vis absorption spectra of compounds $10 \mathrm{a}$ and $\mathbf{1 0 \mathbf { a } ^ { - }}$ recorded for $10 \mu \mathrm{M} \mathrm{CH} \mathrm{CN}_{3}$ solutions. The inset shows the EPR spectrum of $\mathbf{1 0 \mathbf { a } ^ { - }}$ recorded in degassed THF $(g=2.0035)$.

Metal-catalyzed cross-coupling reactions have been previously demonstrated for $E$ BODIPYs ${ }^{75}$ prompting us to conduct a proof-of-concept study to evaluate the suitability of complex 11 to undergo copper-assisted alkyne-azide cycloaddition chemistry as a route to further elaborate the structural diversity associated with dialkynylborane formazante complexes. TMSprotected complex 10e was deprotected using excess $\mathrm{K}_{2} \mathrm{CO}_{3}$ to afford alkyne-substituted complex 11 in 84\% yield (Scheme 4, Figures S23-S25). This transformation was accompanied by a loss of the ${ }^{1} \mathrm{H}$ NMR resonance at $-0.05 \mathrm{ppm}$ associated with the TMS group of 10e and the appearance of a new resonance at $2.22 \mathrm{ppm}$ due to the presence of the free alkyne substituents of 11. Bis(triazolyl)borane complex $\mathbf{1 2}$ was prepared in $38 \%$ yield by combining a mixture of complex 10 and a slight excess of benzyl azide with a catalytic amount of $\mathrm{CuI}$ and $N, N, N^{\prime}, N^{\prime \prime}, N^{\prime \prime}-$ pentamethyldiethylenetriamine (PMDETA) (Scheme 4, Figures S26-S28). The relatively low yield of this reaction was attributed to the sterically congested environment associated with the boron-bound alkyne substituents in compound $\mathbf{1 1}$ and no reaction was observed in the absence of 
CuI. The absence of IR absorptions associated with the alkyne substituents of compound $\mathbf{1 1}$ (3281 and $2060 \mathrm{~cm}^{-1}$ ) and benzyl azide $\left(2094 \mathrm{~cm}^{-1}\right)$ in the IR spectrum of 12 (Figure 5) were consistent with the proposed structure, which was confirmed by NMR spectroscopy and mass spectrometry data. The UV-vis absorption spectra of complexes 10e, 11, and 12 were qualitatively similar to those of complexes 10a-10d with $\lambda_{\max }$ values of 515,524 , and $532 \mathrm{~nm}$, respectively (Figure S29).
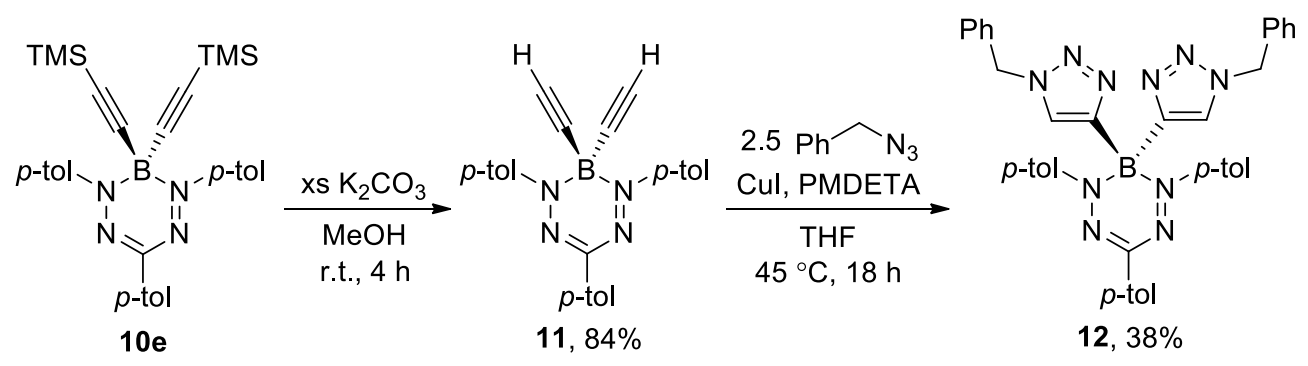

Scheme 4. Deprotection of complex 10e and subsequent alkyne-azide cycloaddition chemistry to form complex 12. 


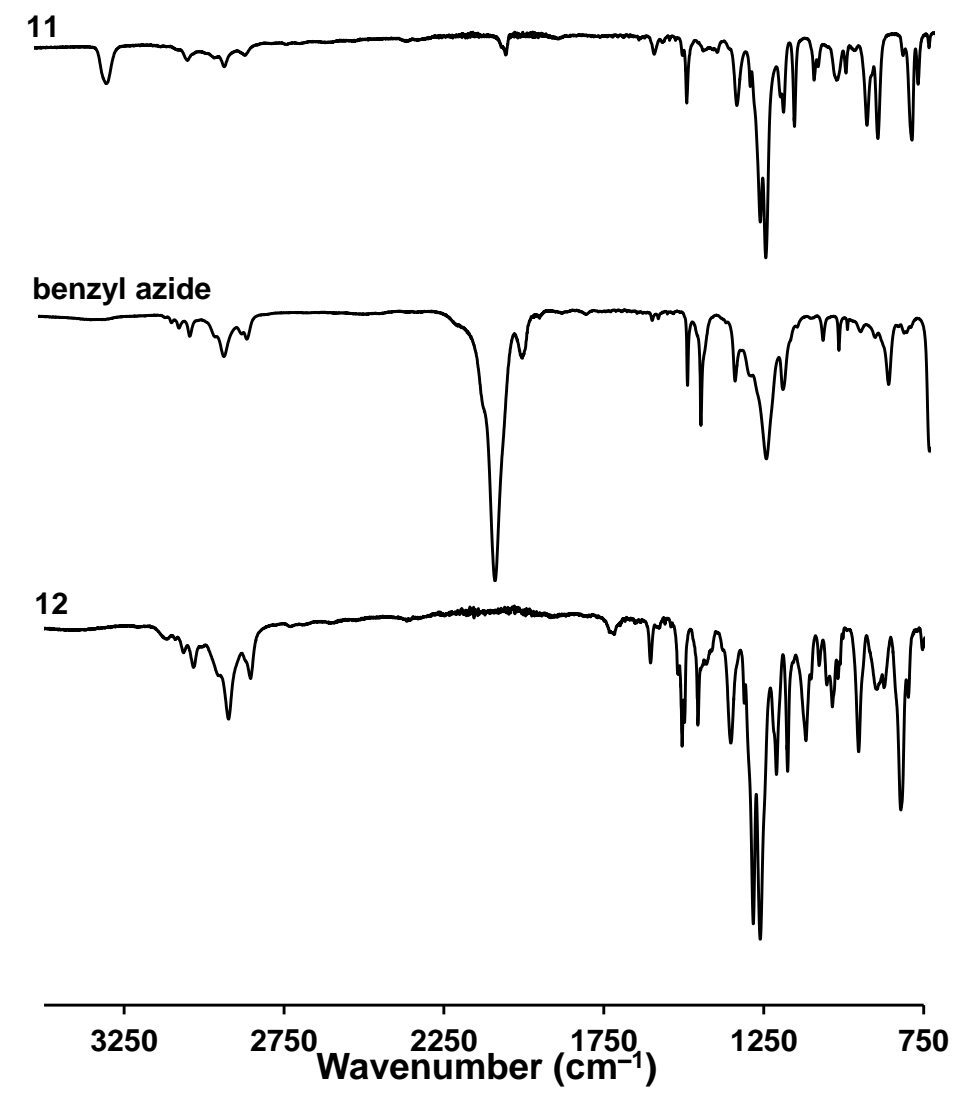

Figure 5. FT-IR spectra of 11, benzyl azide, and $\mathbf{1 2}$.

\section{CONCLUSIONS}

We synthesized a series of novel dialkynylborane complexes, the first based on redoxactive formazanate ligands, by reacting a $\mathrm{BF}_{2}$ formazanate complex with lithium salts of substituted alkynes. The electronic properties of these complexes were studied using UV-vis absorption spectroscopy and cyclic voltammetry. These studies demonstrated that the absorption maxima, and thus HOMO-LUMO gaps, were not dependent on the nature of the alkyne substituents, while similar structural variation affected the potentials at which electrochemical oxidation and reduction occurred. When electron-donating substituents were incorporated, complexes became harder to reduce and easier to oxidize. When electron-withdrawing substituents were introduced, the opposite trend was observed. Chemical reduction of selected 
complexes afforded stable radical anions supported by the formazanate ligand backbone and provide a potential handle for the development of redox sensors. Finally, copper-assisted alkyneazide cycloaddition chemistry was demonstrated to occur at the boron-bound alkynyl substituents of one of our complexes, opening the door to an entirely new mode of reactivity for this class of compounds that should lead to the development of novel functional molecular materials based on dialkynylborane complexes of a variety of $N$-donor ligands in the future.

\section{ASSOCIATED CONTENT}

\section{Supporting Information}

The supporting information is available free of charge on the ACS Publications website at DOI: \#\#\#\#\#\#.

X-ray crystallography methods, data collection and refinement details; ${ }^{1} \mathrm{H},{ }^{11} \mathrm{~B},{ }^{13} \mathrm{C}\left\{{ }^{1} \mathrm{H}\right\}$, and ${ }^{19}$ F NMR spectra for diamagnetic compounds; additional UV-vis absorption and EPR spectra.

\section{AUTHOR INFORMATION}

\section{Corresponding Authors}

*E-mail: mworkent@uwo.ca; joe.gilroy@uwo.ca. Tel: +1 (519) 661-2111 ext. 86319 (M.S.W.)/ +1 (519) 661-2111 ext. 81561 (J.B.G.).

\section{Author Contributions}

The manuscript was written through contributions of all authors. All authors have given approval of the final version of the manuscript.

\section{Notes}

The authors declare no competing financial interests. 


\section{ACKNOWLEDGEMENTS}

This work was supported by the Natural Sciences and Engineering Research Council (NSERC) of Canada (M.S.W.: DG, RGPIN-2017-04637, J.B.G.: DG, RGPIN-2018-04240, R.R.M.: CGSD Scholarship), the Ontario Ministry of Research and Innovation (J.B.G.: ERA, ER-14-10-147) and the Canadian Foundation for Innovation (J.B.G.: JELF, 33977). The authors thank Dr. Paul Bazylewski and Dr. Giovanni Fanchini for assistance with EPR measurements and access to instrumentation.

\section{REFERENCES}

(1) Loudet, A.; Burgess, K. BODIPY Dyes and Their Derivatives: Syntheses and Spectroscopic Properties. Chem. Rev. 2007, 107, 4891-4932.

(2) Frath, D.; Massue, J.; Ulrich, G.; Ziessel, R. Luminescent Materials: Locking $\pi$-Conjugated and Heterocyclic Ligands with Boron(III). Angew. Chem. Int. Ed. 2014, 53, 2290-2310.

(3) Ni, Y.; Wu, J. Far-Red and Near Infrared BODIPY Dyes: Synthesis and Applications for Fluorescent pH Probes and Bio-imaging. Org. Biomol. Chem. 2014, 12, 3774-3791.

(4) Kowada, T.; Maeda, H.; Kikuchi, K. BODIPY-Based Probes for the Fluorescence Imaging of Biomolecules in Living Cells. Chem. Soc. Rev. 2015, 44, 4953-4972.

(5) Ulrich, G.; Goze, C.; Guardigli, M.; Roda, A.; Ziessel, R. Pyrromethene Dialkynyl Borane Complexes for "Cascatelle" Energy Transfer and Protein Labeling. Angew. Chem. Int. Ed. 2005, 44, 3694-3698.

(6) Harriman, A.; Izzet, G.; Ziessel, R. Rapid Energy Transfer in Cascade-Type BODIPY Dyes. J. Am. Chem. Soc. 2006, 128, 10868-10875. 
(7) Rachford, A. A.; Ziessel, R.; Bura, T.; Retailleau, P.; Castellano, F. N. Boron Dipyrromethene (BODIPY) Phosphorescence Revealed in $\left[\operatorname{Ir}(\mathrm{ppy})_{2}(\mathrm{bpy}-\mathrm{C} \equiv \mathrm{C}-\mathrm{BODIPY}]^{+}\right.$. Inorg. Chem. 2010, 49, 3730-3736.

(8) Suk, J.; Omer, K. M.; Bura, T.; Ziessel, R.; Bard, A. J. Electrochemistry and Electrogenerated Chemiluminescence of Some BODIPY Derivatives. J. Phys. Chem. C 2011, 115, 15361-15368.

(9) Lu, J.-s.; Ko, S.-B.; Walters, N. R.; Wang, S. N. Decorating BODIPY with Three- and FourCoordinate Boron Groups. Org. Lett. 2012, 14, 5660-5663.

(10) Berhe, S. A.; Rodriguez, M. T.; Park, E.; Nesterov, V. N.; Pan, H.; Youngblood, W. J. Optoelectronic Tuning of Organoborylazadipyrromethenes via Effective Electronegativity at the Metalloid Center. Inorg. Chem. 2014, 53, 2346-2348.

(11) Maligaspe, E.; Pundsack, T. J.; Albert, L. M.; Zatsikha, Y. V.; Solntsev, P. V.; Blank, D. A.; Nemykin, V. N. Synthesis and Charge-Transfer Dynamics in a Ferrocene-Containing Organoboryl aza-BODIPY Donor-Acceptor Triad with Boron as the Hub. Inorg. Chem. 2015, 54, 4167-4174.

(12) Patalag, L. J.; Jones, P. G.; Werz, D. B. BOIMPYs: Rapid Access to a Family of RedEmissive Fluorophores and NIR Dyes. Angew. Chem. Int. Ed. 2016, 55, 13340-13344.

(13) Maeda, C.; Nagahata, K.; Ema, T. Carbazole-Based BODIPYs with Ethynyl Substituents at the Boron Center: Solid-State Excimer Fluorescence in the VIS/NIR Region. Org. Biomol. Chem. 2017, 15, 7783-7788.

(14) Harriman, A.; Mallon, L. J.; Elliot, K. J.; Haefele, A.; Ulrich, G.; Ziessel, R. Length Dependence for Intramolecular Energy Transfer in Three- and Four-Color Donor-SpacerAcceptor Arrays. J. Am. Chem. Soc. 2009, 131, 13375-13386. 
(15) Bura, T.; Retailleau, P.; Ziessel, R. Efficient Synthesis of Panchromatic Dyes for Energy Concentration. Angew. Chem. Int. Ed. 2010, 49, 6659-6663.

(16) Ziessel, R.; Ulrich, G.; Haefele, A.; Harriman, A. An Artificial Light-Harvesting Array Constructed from Multiple Bodipy Dyes. J. Am. Chem. Soc. 2013, 135, 11330-11344.

(17) Roland, T.; Heyer, E.; Liu, L.; Ruff, A.; Ludwigs, S.; Ziessel, R.; Haacke, S. A Detailed Analysis of Multiple Photoreactions in a Light-Harvesting Molecular Triad with Overlapping Spectra by Utrafast Spectroscopy. J. Phys. Chem. C 2014, 118, 24290-24301.

(18) Jagtap, K. K.; Shivran, N.; Mula, S.; Naik, D. B.; Sarkar, S. K.; Mukherjee, T.; Maity, D. K.; Ray, A. K. Change of Boron Substitution Improves the Lasing Performance of BODIPY Dyes: A Mechanistic Rationalisation. Chem. Eur. J. 2013, 19, 702-707.

(19) Duran-Sampedro, G.; Esnal, I.; Agarrabeitia, A. R.; Bañuelos Prieto, J.; Cerdán, L.; GarcíaMoreno, I.; Costela, A.; Lopez-Arbeloa, I.; Ortiz, M. J. First Highly Efficient and Photostable $E$ and $C$ Derivatives of 4,4-Difluoro-4-bora-3a,4a-diaza-s-indacene (BODIPY) as Dye Lasers in the Liquid Phase, Thin Films, and Solid-State Rods. Chem. Eur. J. 2014, $20,2646-2653$.

(20) Didier, P.; Ulrich, G.; Mély, Y.; Ziessel, R. Improved Push-Pull-Push E-BODIPY Fluorophores for Two-Photon Cell-Imaging. Org. Biomol. Chem. 2009, 7, 3639-3642.

(21) Poirel, A.; Retailleau, P.; De Nicola, A.; Ziessel, R. Synthesis of Water-Soluble RedEmitting Thienyl-BODIPYs and Bovine Serum Albumin Labeling. Chem. Eur. J. 2014, 20, $1252-1257$.

(22) Fan, G.; Lin, Y.-X.; Yang, L.; Gao, F.-P.; Zhao, Y.-X.; Qiao, Z.-Y.; Zhao, Q.; Fan, Y.-S.; Chen, Z; Wang, H. Co-Self-Assembled Nanoaggregates of BODIPY Amphiphiles for Dual Colour Imaging of Live Cells. Chem. Commun. 2015, 51, 12447-12450. 
(23) Zhang, J.; Yang, M.; Mazi, W.; Adhikari, K.; Fang, M.; Xie, F.; Valenzano, L.; Tiwari, A.; Luo, F.-T.; Liu, H. Unusual Fluorescent Responses of Morpholine-Functionalized Fluorescent Probes to $\mathrm{pH}$ via Manipulation of BODIPY's HOMO and LUMO Energy Orbitals for Intracellular pH Detection. ACS Sens. 2016, 1, 158-165.

(24) Filatov, M. A.; Karuthedath, S.; Polestshuk, P. M.; Savoie, H.; Flanagan, K. J.; Sy, C.; Sitte, E.; Telitchko, M.; Laquai, F.; Boyle, R. W.; Senge, M. O. Generation of Triplet Excited States via Photoinduced Electron Transfer in Meso-Anthra-BODIPY: Fluorogenic Response toward Singlet Oxygen in Solution and in Vitro. J. Am. Chem. Soc. 2017, 139, $6282-6285$.

(25) Kumaresan, D.; Thummel, R. P.; Bura, T.; Ulrich, G.; Ziessel, R. Color Tuning in New Metal-Free Organic Sensitizers (BODIPYs) for Dye-Sensitized Solar Cells. Chem. Eur. J. 2009, 15, 6335-6339.

(26) Rousseau, T.; Cravino, A.; Bura, T.; Ulrich, G.; Ziessel, R.; Roncali, J. Multi-Donor Molecular Bulk Heterojunction Solar Cells: Improving Conversion Efficiency by Synergistic Dye Combinations. J. Mater. Chem. 2009, 19, 2298-2300.

(27) Bura, T.; Leclerc, N.; Fall, S.; Lévêque, P.; Heiser, T.; Ziessel, R. Absorption Tuning of Monosubstituted Triazatruxenes for Bulk Heterojunction Solar Cells. Org. Lett. 2011, 13, 6030-6033.

(28) Sutter, A.; Retailleau, P.; Huang, W.-C.; Lin, H.-W.; Ziessel, R. Photovoltaic Performance of Novel Push-Pull-Push Thienyl-BODIPY Dyes in Solution-Processed BHJ-Solar Cells. New J. Chem. 2014, 38, 1701-1710. 
(29) Nagai, A.; Kokado, K.; Miyake, J.; Chujo, Y. Highly Luminescent Nanoparticles: SelfAssembly of Well-Defined Block Copolymers by $\pi-\pi$ Stacked BODIPY Dyes as Only a Driving Force. Macromolecules 2009, 42, 5446-5452.

(30) Kaloudi-Chantzea, A.; Karakostas, N.; Raptopoulou, C. P.; Psycharis, V.; Saridakis, E.; Griebel, J.; Hermann, R.; Pistolis, G. Coordination-Driven Self Assembly of a Brilliantly Fluorescent Rhomboid Cavitand Composed of BODIPY-Dye Subunits. J. Am. Chem. Soc. 2010, 132, 16327-16329.

(31) Iehl, J.; Nierengarten, J.-F.; Harriman, A.; Bura, T.; Ziessel, R. Artificial Light-Harvesting Arrays: Electronic Energy Migration and Trapping on a Sphere and between Spheres. $J$. Am. Chem. Soc. 2012, 134, 988-998.

(32) Olivier, J.-H.; Barberá, J.; Bahaidarah, E.; Harriman, A.; Ziessel, R. Self-Assembly of Charged BODIPY Dyes To Form Cassettes That Display Intracomplex Electronic Energy Transfer and Accrete into Liquid Crystals. J. Am. Chem. Soc. 2012, 134, 6100-6103.

(33) Kaloudi-Chantzea, A.; Karakostas, N.; Pitterl, F.; Raptopoulou, C. P.; Glezos, N.; Pistolis, G. Efficient Supramolecular Synthesis of a Robust Circular Light-Harvesting BODIPYDye Based Array. Chem. Commun. 2012, 48, 12213-12215.

(34) Mula, S.; Frein, S.; Russo, V.; Ulrich, G.; Ziessel, R.; Barberá, J.; Deschenaux, R. Red and Blue Liquid-Crystalline Borondipyrromethene Dendrimers. Chem. Mater. 2015, 27, 2332 2342.

(35) Yang, L.; Fan, G.; Ren, X.; Zhao, L.; Wang, J.; Chen, Z. Aqueous Self-Assembly of a Charged BODIPY Amphiphile via Nucleation-Growth Mechanism. Phys. Chem. Chem. Phys. 2015, 17, 9167-9172. 
(36) Karakostas, N.; Mavridis, I. M.; Seintis, K.; Fakis, M.; Koini, E. N.; Petsalakis, I. D.; Pistolis, G. Highly Efficient and Unidirectional Energy Transfer within a Tightly SelfAssembled Host-Guest Multichromophoric Array. Chem. Commun. 2014, 50, 1362-1365.

(37) Kaloudi-Chantzea, A.; Martinou, E.; Seintis, K.; Karakostas, N.; Giastas, P.; Pitterl, F.; Oberacher, H.; Fakis, M.; Pistolis, G. Formation of a Highly-Ordered Rigid Multichromophoric 3D Supramolecular Network by Combining Ionic and CoordinationDriven Self-Assembly. Chem. Commun. 2016, 52, 3388-3391.

(38) Gilroy, J. B.; Patrick, B. O.; McDonald, R.; Hicks, R. G. Transition Metal Complexes of 3Cyano- and 3-Nitroformazans. Inorg. Chem. 2008, 47, 1287-1294.

(39) Hong, S.; Hill, L. M. R.; Gupta, A. K.; Naab, B. D.; Gilroy, J. B.; Hicks, R. G.; Cramer, C. J.; Tolman, W. B. Effects of Electron-Deficient $\beta$-Diketiminate and Formazan Supporting Ligands on Copper(I)-Mediated Dioxygen Activation. Inorg. Chem. 2009, 48, 4514-4523.

(40) Chang, M.-C.; Dann, T.; Day, D. P.; Lutz, M.; Wildgoose, G. G.; Otten, E. The Formazanate Ligand as an Electron Reservoir: Bis(Formazanate) Zinc Complexes Isolated in Three Redox States. Angew. Chem. Int. Ed. 2014, 53, 4118-4122.

(41) Travieso-Puente, R.; Chang, M.-C.; Otten, E. Alkali Metal Salts of Formazanate Ligands: Diverse Coordination Modes as a Result of the Nitrogen-Rich [NNCNN] Ligand Backbone. Dalton Trans. 2014, 43, 18035-18041.

(42) Chang, M.-C.; Roewen, P.; Travieso-Puente, R.; Lutz, M.; Otten, E. Formazanate Ligands as Structurally Versatile, Redox-Active Analogues of $\beta$-Diketiminates in Zinc Chemistry. Inorg. Chem. 2015, 54, 379-388. 
(43) Mandal, A.; Schwederski, B.; Fiedler, J.; Kaim, W.; Lahiri, G. K. Evidence for Bidirectional Noninnocent Behavior of a Formazanate Ligand in Ruthenium Complexes. Inorg. Chem. 2015, 54, 8126-8135.

(44) Protasenko, N. A.; Poddel'sky, A. I.; Bogomyakov, A. S.; Fukin, G. K.; Cherkasov, V. K. Heteroligand o-Semiquinonato-Formazanato Cobalt Complexes. Inorg. Chem. 2015, 54, 6078-6080.

(45) Kabir, E.; Wu, C.-H.; Wu, J. I.-C.; Teets, T. S. Heteroleptic Complexes of Cyclometalated Platinum with Triarylformazanate Ligands. Inorg. Chem. 2016, 55, 956-963.

(46) Travieso-Puente, R.; Broekman, J. O. P.; Chang, M.-C.; Demeshko, S.; Meyer, F.; Otten, E. Spin-Crossover in a Pseudo-tetrahedral Bis(formazanate) Iron Complex. J. Am. Chem. Soc. 2016, 138, 5503-5506.

(47) Maar, R. R.; Rabiee Kenaree, A.; Zhang, R.; Tao, Y.; Katzman, B. D.; Staroverov, V. N.; Ding, Z. F.; Gilroy, J. B. Aluminum Complexes of $\mathrm{N}_{2} \mathrm{O}_{2}{ }^{3-}$ Formazanate Ligands Supported by Phosphine Oxide Donors. Inorg. Chem. 2017, 56, 12436-12447.

(48) Milocco, F.; Demeshko, S.; Meyer, F.; Otten, E. Ferrate(II) Complexes with Redox-Active Formazanate Ligands. Dalton Trans. 2018, 47, 8817-8823.

(49) Maar, R. R.; Catingan, S. D.; Staroverov, V. N.; Gilroy, J. B. Formazanate Complexes of Hypervalent Group 14 Elements as Precursors to Electronically Stabilized Radicals. Angew. Chem. Int. Ed. 2018, 57, 9870-9874.

(50) Broere, D. L. J.; Mercado, B. Q.; Lukens, J. T.; Vilbert, A. C.; Banerjee, G.; Lant, H. M. C.; Lee, S. H.; Bill, E.; Sproules, S.; Lancaster, K. M.; Holland, P. L. Reversible LigandCentered Reduction in Low-Coordinate Iron Formazanate Complexes. Chem. Eur. J. 2018, 24, 9417-9425. 
(51) Broere, D. L. J.; Mercado, B. Q.; Holland, P. L. Selective Conversion of $\mathrm{CO}_{2}$ into Isocyanate by Low-Coordinate Iron Complexes. Angew. Chem. Int. Ed. 2018, 57, 65076511.

(52) Kabir, E.; Patel, D.; Clark, K.; Teets, T. S. Spectroscopic and Electrochemical Properties of Electronically Modified Cycloplatinated Formazanate Complexes. Inorg. Chem. 2018, 57, 10906-10917.

(53) Chang, M.-C.; Otten, E. Synthesis and Ligand-Based Reduction Chemistry of Boron Difluoride Complexes with Redox-Active Formazanate Ligands. Chem. Commun. 2014, 50, $7431-7433$.

(54) Barbon, S. M.; Reinkeluers, P. A.; Price, J. T.; Staroverov, V. N.; Gilroy, J. B. Structurally Tunable 3-Cyanoformazanate Boron Difluoride Dyes. Chem. Eur. J. 2014, 20, 1134011344.

(55) Barbon, S. M.; Staroverov, V. N.; Gilroy, J. B. Effect of Extended $\pi$ Conjugation on the Spectroscopic and Electrochemical Properties of Boron Difluoride Formazanate Complexes. J. Org. Chem. 2015, 80, 5226-5235.

(56) Maar, R. R.; Barbon, S. M.; Sharma, N.; Groom, H.; Luyt, L. G.; Gilroy, J. B. Evaluation of Anisole-Substituted Boron Difluoride Formazanate Complexes for Fluorescence Cell Imaging. Chem. Eur. J. 2015, 21, 15589-15599.

(57) Maar, R. R.; Gilroy, J. B. Aggregation-Induced Emission Enhancement in Boron Difluoride Complexes of 3-Cyanoformazanates. J. Mater. Chem. C. 2016, 4, 6478-6482.

(58) Chang, M.-C.; Chantzis, A.; Jacquemin, D.; Otten, E. Boron Difluorides with Formazanate Ligands: Redox-Switchable Fluorescent Dyes with Large Stokes Shifts. Dalton Trans. 2016, 45, 9477-9484. 
(59) Barbon, S. M.; Novoa, S.; Bender, D.; Groom, H.; Luyt, L. G.; Gilroy, J. B. CopperAssisted Azide-Alkyne Cycloaddition Chemistry as a Tool for the Production of Emissive Boron Difluoride 3-Cyanoformazanates. Org. Chem. Front. 2017, 4, 178-190.

(60) Hesari, M.; Barbon, S. M.; Staroverov, V. N.; Ding, Z.; Gilroy, J. B. Efficient Electrochemiluminescence of a Readily Accessible Boron Difluoride Formazanate Dye. Chem. Commun. 2015, 51, 3766-3769.

(61) Hesari, M.; Barbon, S. M.; Mendes, R. B.; Staroverov, V. N.; Ding, Z.; Gilroy, J. B. Structural Tuning of Boron Difluoride Formazanate Electrochemiluminescence Mediated by Tri-n-propylamine. J. Phys. Chem. C 2018, 122, 1258-1266.

(62) Chang, M.-C.; Otten, E. Reduction of (Formazanate)boron Difluoride Provides Evidence for an $N$-Heterocyclic B(I) Carbenoid Intermediate. Inorg. Chem. 2015, 54, 8656-8664.

(63) Barbon, S. M.; Staroverov, V. N.; Gilroy, J. B. Structurally Diverse Boron-Nitrogen Heterocycles from an $\mathrm{N}_{2} \mathrm{O}_{2}{ }^{3-}$ Formazanate Ligand. Angew. Chem. Int. Ed. 2017, 56, 81738177.

(64) Barbon, S. M.; Gilroy, J. B. Boron Difluoride Formazanate Copolymers with 9,9-Di-nHexylfluorene Prepared by Copper-Catalyzed Alkyne-Azide Cycloaddition Chemistry. Polym. Chem. 2016, 7, 3589-3598.

(65) Novoa, S.; Paquette, J. A.; Barbon, S. M.; Maar, R. R.; Gilroy, J. B. Side-Chain Boron Difluoride Formazanate Polymers via Ring-Opening Metathesis Polymerization. J. Mater. Chem. C 2016, 4, 3987-3994.

(66) Novoa, S.; Gilroy, J. B. (Co)polymers Containing Boron Difluoride 3-Cyanoformazanate Complexes: Emission Enhancement via Random Copolymerization. Polym. Chem. 2017, 8, $5388-5395$. 
(67) Dhindsa, J. S.; Maar, R. R.; Barbon, S. M.; Olivia Avilés, M.; Powell, Z. K.; LagugnéLabarthet, F.; Gilroy, J. B. A $\pi$-Conjugated Inorganic Polymer Constructed from Boron Difluoride Formazanates and Platinum(II) Diynes. Chem. Commun. 2018, 54, 6899-6902.

(68) Mondol, R.; Otten, E. Reactivity of Two-Electron-Reduced Boron Formazanate Compounds with Electrophiles: Facile $\mathrm{N}-\mathrm{H} / \mathrm{N}-\mathrm{C}$ Bond Homolysis due to the Formation of Stable Ligand Radicals. Inorg. Chem. 2018, 57, 9720-9727.

(69) Barbon, S. M.; Price, J. T.; Reinkeluers, P. A.; Gilroy, J. B. Substituent-Dependent Optical and Electrochemical Properties of Triarylformazanate Boron Difluoride Complexes. Inorg. Chem. 2014, 53, 10585-10593.

(70) Gilroy, J. B.; McKinnon, S. D. J.; Koivisto, B. D.; Hicks, R. G. Electrochemical Studies of Verdazyl Radicals. Org. Lett. 2007, 9, 4837-4840.

(71) Goze, C.; Ulrich, G.; Ziessel, R. Tetrahedral Boron Chemistry for the Preparation of Highly Efficient "Cascatelle" devices. J. Org. Chem. 2007, 72, 313-322.

(72) Rumble, J. R., CRC Handbook of Chemistry and Physics, 98th Edition, CRC Press/Taylor and Francis, Boca Raton, FL.

(73) Ziessel, R.; Goze, C.; Ulrich, G. Design and Synthesis of Alkyne-Substituted Boron in Dipyrromethene Frameworks. Synthesis 2007, 936-949.

(74) Gilroy, J. B.; Ferguson, M. J.; McDonald, R.; Patrick, B. O.; Hicks, R. G. Formazans as $\beta$ Diketiminate Analogues. Structural Characterization of Boratatetrazines and their Reduction to Borataverdazyl Radical Anions. Chem. Commun. 2007, 126-128.

(75) Goze, C.; Ulrich, G.; Ziessel, R. Unusual Fluorescent Monomeric and Dimeric Dialkynyl Dipyrromethene-Borane Complexes. Org. Lett. 2006, 8, 4445-4448. 


\section{For Table of Contents Only}

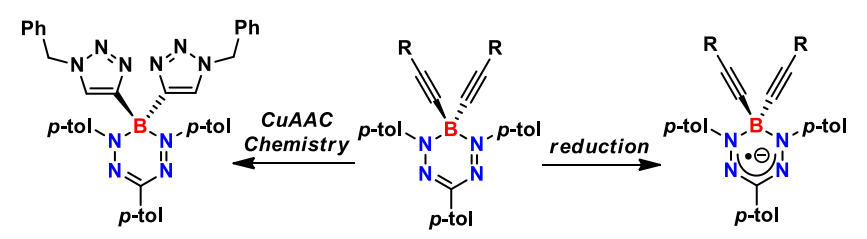

Dialkynylborane complexes of formazanate ligands were generated from the corresponding boron difluoride complex. The alkynyl substituents employed had little influence over lowenergy UV-Vis absorption properties, but did affect redox potentials. The title complexes were converted to stable radical anions and copper-assisted alkyne-azide cycloaddition chemistry was used to elaborate structural diversity. 